\title{
Dynamics of dissolved nutrients in the aquaculture shrimp ponds of the Min River estuary, China: Concentrations, fluxes and environmental loads
}

Ping Yang, Derrick Y. F. Lai, Baoshi J in, David Bastviken, Lishan Tan and Chuan Tong

The self-archived postprint version of this journal article is available at Linköping University Institutional Repository (DiVA):

http:/ / urn.kb.se/ resolve?urn=urn:nbn:se:liu:diva-139803

N.B.: When citing this work, cite the original publication.

Yang, P., Lai, D. Y. F., J in, B., Bastviken, D., Tan, L., Tong, C., (2017), Dynamics of dissolved nutrients in the aquaculture shrimp ponds of the Min River estuary, China: Concentrations, fluxes and environmental loads, Science of the Total Environment, 603, 256-267.

https:// doi.org/ 10.1016/j.scitotenv.2017.06.074

Original publication available at:

https:// doi.org/ 10.1016/j.scitotenv.2017.06.074

Copyright: Elsevier

http:// www.elsevier.com/

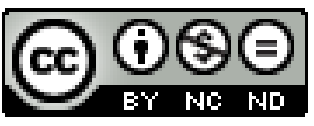


G RA P H I C A L A B S TRAC T

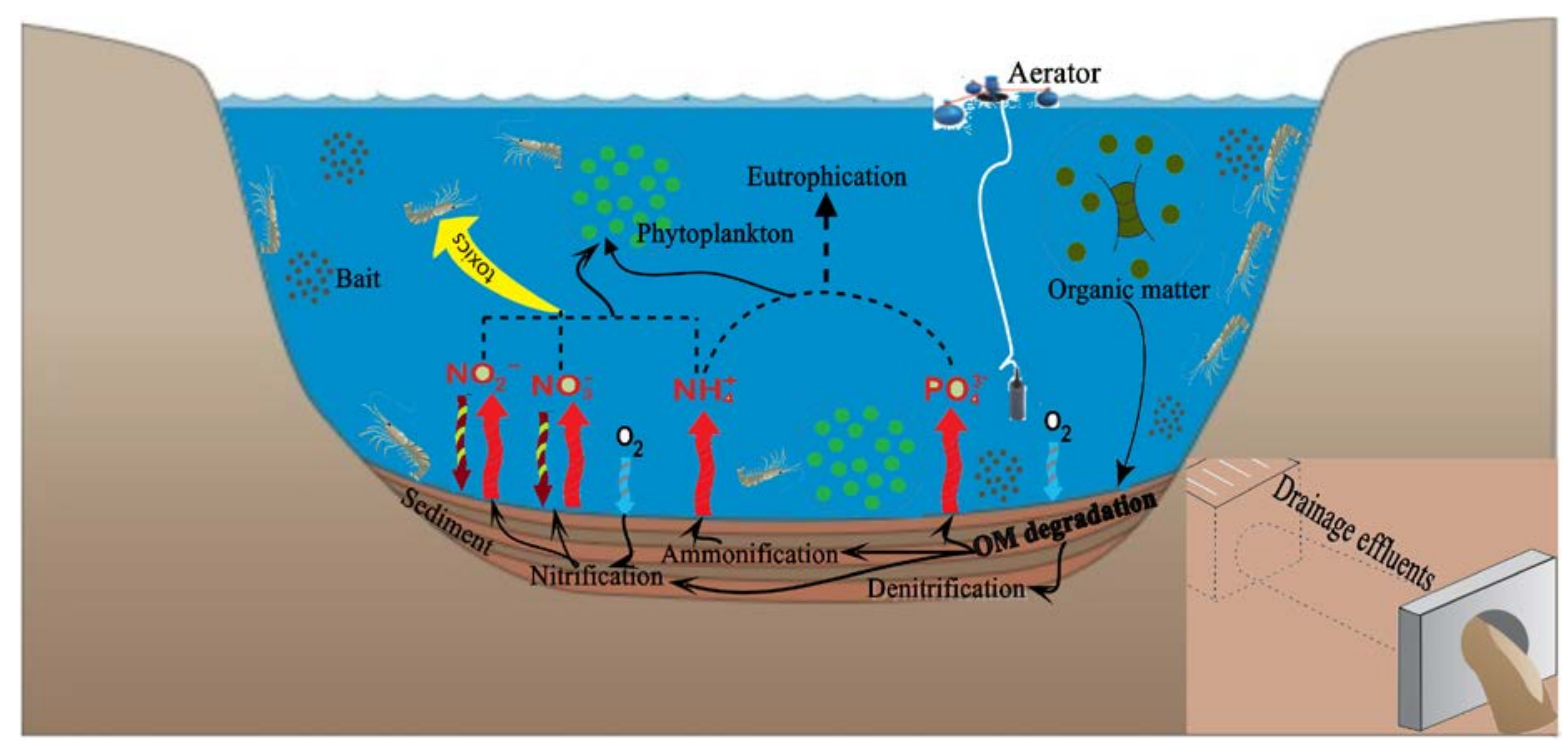

2 


\section{H I G H L I G H T S}

- $\mathrm{NH}_{4}{ }^{+}-\mathrm{N}$ was the predominant species of dissolved inorganic nitrogen in shrimp ponds.

- Dissolved inorganic nutrients varied greatly among different shrimp growth stages.

- Aquaculture pond effluent is a key contributor to China's coastal water pollution. 


\section{Dynamics of dissolved nutrients in the aquaculture shrimp ponds}

\section{of the Min River estuary, China: Concentrations, fluxes and environmental loads}

Ping Yang ${ }^{\mathrm{a}, \mathrm{b}}$, Derrick Y.F. Lai ${ }^{\mathrm{c}}$, Baoshi Jin ${ }^{\mathrm{a}}$, David Bastviken ${ }^{\mathrm{d}}$, Lishan Tan ${ }^{\mathrm{a}}$, Chuan Tong a,b,e*

aSchool of Geographical Sciences, Fujian Normal University, Fuzhou 350007, P.R. China

${ }^{\mathbf{b}}$ Key Laboratory of Humid Subtropical Eco-geographical Process of Ministry of Education, Fujian Normal University, Fuzhou 350007, P.R. China

'Department of Geography and Resource Management, and Centre for Environmental Policy and Resource Management, The Chinese University of Hong Kong, Shatin, New Territories, Hong Kong SAR, China

${ }^{\mathrm{d}}$ Department of Thematic Studies-Environmental Change, Linköping University, Linköping, Sweden ${ }^{\mathrm{e}}$ Research Centre of Wetlands in Subtropical Region, Fujian Normal University, Fuzhou 350007, P.R. China

Correspondence to: Chuan Tong

Telephone: 086-0591-87445659

Fax: 086-0591-83465397

Email: yangping528@sina.cn (P. Yang), tongch@fjnu.edu.cn (C. Tong) 


\section{A B S T R A C T}

Dissolved inorganic nutrients $\left(\mathrm{NO}_{2}^{-}-\mathrm{N}, \mathrm{NO}_{3}{ }^{-}-\mathrm{N}, \mathrm{NH}_{4}{ }^{+}-\mathrm{N}\right.$, and $\left.\mathrm{PO}_{4}{ }^{3-}-\mathrm{P}\right)$ play a critical role in the effective management of water quality and prevention of fish and shrimp diseases in aquaculture systems. In this study, dissolved inorganic nutrient concentrations in the water column and sediment porewater and the fluxes across the sediment-water interface (SWI) were investigated in three intensive shrimp ponds with zero water exchange to examine nutrient cycling during the different growth stages of shrimps. We found distinct changes in the dissolved inorganic nutrient concentrations in both the water column and sediment porewater among the three growth stages. Average $\mathrm{NO}_{2}^{-}-\mathrm{N}, \mathrm{NO}_{3}{ }^{-}-\mathrm{N}, \mathrm{NH}_{4}{ }^{+}-\mathrm{N}$, and $\mathrm{PO}_{4}{ }^{3-}-\mathrm{P}$ concentrations in the sediment porewater were $3.53,2.81,29.68$, and 6.44 times higher, respectively, than those in the water column over the study period, indicating that the pond sediment acted as a net source of nutrients to the water column. This was further supported by the net release of nutrients from the sediments to the water column observed during the incubation experiment. Nutrient fluxes were dominated by $\mathrm{NH}_{4}{ }^{+}-\mathrm{N}$, while $\mathrm{NO}_{\mathrm{x}}{ }^{-}-\mathrm{N}\left(\mathrm{NO}_{2}{ }^{-}-\mathrm{N}\right.$ and $\mathrm{NO}_{3}{ }^{-}-\mathrm{N}$ ) and $\mathrm{PO}_{4}{ }^{3-}-\mathrm{P}$ fluxes remained low. The high rates of $\mathrm{NH}_{4}{ }^{+}-\mathrm{N}$ release from the sediment highlight the need of taking into account the biogeochemical role of sediments in mitigating the problem of water quality degradation in coastal shrimp ponds. Based on a total water surface area of mariculture ponds and a total mariculture production of $2.57 \times 10^{6}$ ha and $2.30 \times 10^{9} \mathrm{~kg}$, respectively, we estimated conservatively that approximately $4.77 \times 10^{4}$ ton of total nitrogen and $3.75 \times 10^{3}$ ton of total phosphorus are being discharged annually from the mariculture ponds into the adjacent coastal zones across China. Our results demonstrated the importance of aquaculture pond effluent as a major contributor of water pollution in the coastal areas of China, and 
called for actions to properly treat these effluents in alleviating the eutrophication problem in the Chinese coastal zones.

Keywords: Porewater; Nutrient dynamics; Sediment-water interface; Prawn culture; Eutrophication; Estuary 


\section{1. Introduction}

Global aquaculture production has increased dramatically over the past 50 years, with an average annual increase rate of $8.3 \%$ during the period of $1970-2008$, to meet the rising demand around the world for protein (FAO, 2010). Intensive shrimp aquaculture (FAO, 2016), in which shrimps are raised at very high densities in closed or semi-closed systems with constant supply of oxygen, water, and feeds, is seen as an important component in sustaining a steady aquaculture production because of its short production cycles and high product values (Silva et al., 2013; Molnar et al., 2013). According to data from the Food and Agriculture Organization (FAO), global food shrimp (prawn) culture reached a total annual production of about 2.1 million tonnes in 2015 (FAO, 2016). Although intensive aquaculture has been very effective in responding to the ever-growing global demand for aquaculture food, it has also been linked to serious environmental problems.

4 One of the key environmental concerns regarding intensive aquaculture is the accumulation of nutrients (especially inorganic nitrogen and phosphorus), which can cause water quality problems within ponds (Hargreaves and Tucker, 2004; Castillo-Soriano et al., 2013; Hu et al., 2014) and subsequently shrimp diseases. In general, intensive aquaculture shrimp ponds are maintained through daily supply of feeds. However, only a small proportion of these nutrient inputs are being converted into shrimp biomass, as the feed utilization efficiency is only about 4.0-27.4\% (Su et al., 2009; Chen et al., 2016). Consequently, the majority of the nutrients in the residual feeds are retained in the pond water. Once the accumulation of nutrients in pond water exceeds the tolerance threshold, adverse effects in the form of harmful algae blooms and water quality deterioration could be seen in the aquaculture ponds (Huang et al., 2016; Yang et al., 2017a). More importantly, high concentrations of nutrients 
26 (especially ammonia and nitrite) in the water column can stimulate the release of corticosteroid hormones into the venous circulation of shrimps (Hu et al., 2014), which may be hazardous to shrimp health and thus cause a reduction in shrimp productivity. Understanding the nutrient dynamics of intensive aquaculture ponds therefore is critical for proper pond management and improvement of shrimp yield.

Another key environmental concern regarding intensive aquaculture is the discharge of pond effluents into the water bodies of the nearby coastal zones. In general, the water column is the main habitat for animals in aquaculture ponds, and its conditions are closely associated with the healthy growth of fish, shrimps, and other organisms (Yang et al., 2017b). Complete drainage of pond water is typically done at the end of each aquaculture production cycle, in order to aerate the bottom soils and discard the water polluted with nutrients and wastes in preparation of the next round of aquaculture production (Wang and Wang, 2007; Wu et al., 2014). During this process, large quantities of water enriched with nutrients are discharged into the adjacent ecosystem over a very short period of around a month (Wu et al., 2014). Such practice can rapidly alter the nutrient levels and quality of nearby waters, and thus create eutrophication problems in the coastal ecosystems. Impacts of the discharge of aquaculture effluents on the water quality in coastal creeks (Wolanski et al., 2000; Burford et al., 2003; Costanzo et al., 2004) and mangrove swamps (Molnar et al., 2013; Cardoso-Mohedano et al., 2016a, 2016b) have already received great attention. However, very few studies have investigated the effects of aquaculture pond effluents on the trophic status of receiving coastal waters (Herbeck et al., 2013). production takes place, land-based aquaculture pond culture is the most important method of shrimp production in freshwater and brackish water systems (FAO, 2010). 
51 China has the world's largest mariculture industry, with a total mariculture pond area 52 and total aquaculture production of $2.57 \times 10^{6}$ ha and $2.30 \times 10^{9} \mathrm{~kg}$, respectively, in 2015 53 (Chen et al., 2016). In view of this, studying the nutrient dynamics of aquaculture ponds 54 in China is essential for promoting the sustainable development of the aquaculture 55 industry and assessing the likely risks of eutrophication of coastal water bodies. The 56 main objectives of this study were to: (1) investigate the temporal variability of dissolved inorganic nutrients in the water column and sediment porewater of aquaculture shrimp ponds in China at different growth stages of shrimps, (2) assess the nutrient fluxes across the sediment-water interface (SWI) of these ponds, and (3) evaluate the impact of effluent discharge from these aquaculture ponds on the trophic status of receiving coastal waters.

\section{Materials and Methods}

\subsection{Study area description}

The study site is located in Shanyutan wetland (ca. 3120 ha) of the Min River estuary in southeast China (Fig. 1). The area has a subtropical monsoon climate, which is relatively warm and wet, with a mean annual temperature of $19.6^{\circ} \mathrm{C}$ and a mean annual precipitation of about 1,350 mm (Tong et al., 2010). Shrimp ponds are a dominant landscape feature in the Min River estuary (Yang et al., 2015). The total area of shrimp ponds in the Shanyutan wetland is about 234 ha. These ponds were converted in 2011 by complete removal of all marsh vegetations. Aquaculture production in the majority of the shrimp ponds occurs between June and November.

\subsection{Shrimp pond system and management}

As the optimal water temperatures for the growth of shrimps (Litopenaeus vannamei) are $22-35^{\circ} \mathrm{C}$, only one crop of shrimps can be produced per year in our study site. Prior to shrimp production, the ponds were filled with estuarine water from the 
Min River estuary using a submerged pump. The water first passed through a $2 \mathrm{~mm}$ mesh bag in order to prevent to the entry of predators and competitors (Guerrero-Galván et al., 1999). Additional input of freshwater into the ponds took place occasionally during rainfall events. No water was discharged from the spillways of the ponds until the end of shrimp harvesting. The water depth in the shrimp ponds over the culture period ranged between 1.1 and $1.5 \mathrm{~m}$, with a mean of $1.4 \mathrm{~m}$.

To assess nutrient cycling during the culture period, water and sediment samples were collected from three commercial shrimp ponds in the Shanyutan wetland $\left(26^{\circ} 01^{\prime} 49^{\prime \prime} \mathrm{N}, 119^{\circ} 37^{\prime} 39^{\prime \prime} \mathrm{E}\right)$ of the estuary (Fig. 1). The basic details of the three ponds are shown in Table 1. Before stocking, each shrimp pond was fertilized with $37.5 \mathrm{~kg}$ ha ${ }^{-1}$ of urea $(46 \% \mathrm{~N})$ and $5.2 \mathrm{~kg} \mathrm{ha}^{-1}$ of phosphate fertilizer $\left(38 \% \mathrm{P}_{2} \mathrm{O}_{5}\right)$. Postlarval (PL) Litopenaeus vannamei shrimps of approximately $0.9-1.2 \mathrm{~cm}$ in length were successively stocked in the ponds from mid- to late-May, and feeding was initiated simultaneously. The shrimp production cycle began on May 15, and lasted for about 163 days. L. vannamei were fed with artificial feeds containing $42 \%$ of crude protein (Yuehai $^{\mathrm{TM}}$, Guangzhou, China) twice per day at 07:00 and 16:00 (local standard time), respectively, by direct application from a small boat. Based on the management practices (e.g. feeding rate, water depth, etc.), water salinity, and shrimp weight, the shrimp grow-out cycle was divided into three different stages (Table 2), which was similar to the classification scheme adopted by Páez-Osuna et al. (1997). The feeding rate was maintained at approximately $10-16,50-55$, and $40-45 \mathrm{~kg} \mathrm{ha}^{-1} \mathrm{~d}^{-1}$ during the initial, intermediate, and final stages, respectively. The exact amount of feed added was determined based on the response of shrimps to the previous feeding (Casillas-Hernández et al., 2006; Liu et al., 2015). On average, a total of 3.5 ton of feeds were applied to each of the three ponds over the culture period (personal 
communications). At each pond, three $1500-\mathrm{W}$ paddlewheel aerators were activated four times a day between 07:00-09:00, 12:00-14:00, 18:00-20:00, and 00:00-03:00 (local standard time). Pond water was completely drained and surface sediment (0-10 $\mathrm{cm})$ was removed after shrimp harvest.

\subsection{Collection and analysis of water samples}

Water sample were collected in the middle of June, August, and October of 2015 that represented the conditions during the initial, middle, and final stages of shrimp production, respectively.

\subsubsection{Collection and analysis of nutrient concentrations in the water column}

Three replicate sampling sites were established in each pond for water sampling.

Water samples were collected at three different depths of the water column, including the bottom layer at approximately $5 \mathrm{~cm}$ above the soil, the surface layer at approximately $10 \mathrm{~cm}$ below the water surface, and the middle layer at approximately 70-85 cm below the water surface. Water samples from each of the three depths were collected four times at 08:00, 11:00, 14:00, and 17:00 (local time) on each sampling day with a $5 \mathrm{~L}$ Niskin bottle, and then transferred to $250 \mathrm{~mL}$ polyethylene bottles. Approximately $0.2 \mathrm{~mL}$ of saturated $\mathrm{HgCl}_{2}$ solution was injected into each bottle to inhibit microbial activity (Zhang et al., 2013). The water samples were subsequently stored in a $4{ }^{\circ} \mathrm{C}$ cooler, transport to the laboratory, and analysed within one week. For the analysis of dissolved inorganic nutrients, the water samples were filtered through a $0.45 \mu \mathrm{m}$ cellulose acetate filter (Biotrans ${ }^{\mathrm{TM}}$ nylon membranes), and the filtrates were analysed for the concentrations of dissolved inorganic nutrients using a flow injection analyser (Skalar Analytical $\mathrm{SAN}^{++}$, Netherlands). $\mathrm{NO}_{3}^{-}-\mathrm{N}$ was calculated as the difference between $\mathrm{NO}_{\mathrm{x}}{ }^{-}-\mathrm{N}$ and $\mathrm{NO}_{2}{ }^{-}-\mathrm{N}$, while dissolved inorganic nitrogen (DIN) was determined by summing up the concentrations of $\mathrm{NO}_{3}{ }^{-}-\mathrm{N}, \mathrm{NO}_{2}{ }^{-}-\mathrm{N}$, and $\mathrm{NH}_{4}{ }^{+}-\mathrm{N}$ 
126 (David et al., 2016). The detection limits for $\mathrm{NO}_{2}^{-}-\mathrm{N}, \mathrm{NO}_{\mathrm{X}}^{-}-\mathrm{N}, \mathrm{NH}_{4}{ }^{+}-\mathrm{N}$, and $\mathrm{PO}_{4}{ }^{3-}-\mathrm{P}$ 127 were $0.02,0.1,0.1$, and $0.05 \mu \mathrm{mol} \mathrm{L}{ }^{-1}$, respectively. The relative standard deviations of 128 all analyses were in the range of $0.1-4.0 \%$.

\section{9 \\ 2.3.2. Physicochemical and biological parameters of the water column}

In the field, physicochemical variables including water temperature, $\mathrm{pH}$, and 131 salinity were determined via a $\mathrm{pH} / \mathrm{mV} /$ Temp system (IQ150, IQ Scientific Instruments, 132 USA) and a salinity meter (Eutech Instruments-Salt6, USA). The dissolved oxygen 133 (DO) level at various depths of the water column was measured in situ using a 134 multi-parameter controller (HORIBA, Japan). All these instruments were calibrated in 135 the laboratory every time before actual field measurement according to the instruction 136 manuals. Chlorophyll $a(\mathrm{Chl} a)$, which served as a proxy of phytoplankton biomass 137 (Lacoste and Gaertner-Mazouni, 2016), was determined by filtering $250 \mathrm{~mL}$ of water 138 samples through GF/F glass microfibre filters. Following the extraction of filters at $4^{\circ} \mathrm{C}$ 139 in $90 \%(\mathrm{~V} / \mathrm{V})$ acetone for $24 \mathrm{~h}$ and the centrifugation of the mixture at $4500 \mathrm{rpm}$ for 15 $140 \mathrm{~min}$, the absorbance of the supernatant at 665 and $750 \mathrm{~nm}$ was measured using a 141 UV-visible spectrophotometer (Shimadzu UV-2450, Japan) (Zhang et al., 2016; Yang 142 et al., 2017b). The relative standard deviations of this analysis were in the range of $1435-8 \%$. At each growth stage, 50 shrimps were captured from each sampling location 144 using a small bow net. The shrimps were then weighed individually with a portable 145 electronic scale up to a precision of $0.01 \mathrm{~g}$ for determining the shrimp biomass ( $\mathrm{g} \mathrm{PL}^{-1}$ ) 146 at each stage.

\subsection{Collection and analysis of sediment samples}

148 On each sampling day, nine intact sediment cores were collected in each pond by 149 means of $30 \mathrm{~cm}$ long Plexiglas tubes (internal diameter of $6.0 \mathrm{~cm}$ ) that were inserted 150 into a surface-operated coring device (Core-60, Austria) equipped with a core cylinder 
151 and a one-way check valve to preserve the sediment and the overlying water integrity

152 (Han et al., 2014). The intact cores consisted of $15 \mathrm{~cm}$ of sediment overlaid by $15 \mathrm{~cm}$ of

153 water column. These sediment cores were sealed and stored vertically in a $4{ }^{\circ} \mathrm{C}$ cooler

154 and transported to the laboratory within $4 \mathrm{~h}$.

155 2.4.1. Physicochemical parameters of the sediment

156 Triplicate sediment samples $(0-15 \mathrm{~cm})$ from each pond were freeze-dried, 157 homogenized, and then grounded to a fine powder for the analyses of total nitrogen 158 (TN), pH, grain composition, and porosity (Zhou et al., 2016). Sediment TN was 159 analysed with a CHN elemental analyser (Elementar Vario MAX CN, Germany) on 160 oven-dried and grounded subsamples that passed through a $2 \mathrm{~mm}$ sieve. Sediment $\mathrm{pH}$ 161 was determined using a pH meter (Orion 868, USA) with a soil-to-water ratio of 1:2.5. 162 In addition, sediment porosity $(\Phi)$ was estimated based on the water content in surface 163 sediment samples (from a subsample taken before freeze drying) that was determined 164 by weight differences after drying in an oven at $105^{\circ} \mathrm{C}$ for $24 \mathrm{~h}$ (Zhang et al., 2013).

165 2.4.2. Collection and analysis of nutrient in the sediment porewater

166 Triplicate sediment samples $(0-15 \mathrm{~cm})$ from each pond were used to determine the 167 porewater nutrient concentrations. Sediment porewater was collected following the 168 methods described by De Vittor et al. (2012) and Zhang et al. (2013). Briefly, upon 169 return to the laboratory, the sediment cores were extruded and then sliced at $3 \mathrm{~cm}$ 170 intervals. Porewater from each depth interval was extracted from the sediment by 171 centrifugation (5000 rpm, $10 \mathrm{~min}$, Cence ${ }^{\circledR}$ L550) at in situ temperature and then 172 filtered (0.45 $\mu \mathrm{m}$ acetate fibre membranes) (De Vittor et al., 2012). The filtered 173 porewater samples were collected in vials pre-cleaned with acid, and $0.2 \mathrm{~mL}$ of 174 saturated $\mathrm{HgCl}_{2}$ solution was injected into each vial to inhibit microbial activity (Zhang 175 et al., 2013). To prevent oxidation during handling, all porewater samples were 
processed in a nitrogen-filled glove bag (Matos et al., 2016). All filtered porewater samples were stored at $4{ }^{\circ} \mathrm{C}$ until analysis. Concentrations of $\mathrm{NO}_{2}^{-}-\mathrm{N}, \mathrm{NO}_{3}^{-}-\mathrm{N}$, $\mathrm{NH}_{4}{ }^{+}-\mathrm{N}$, and $\mathrm{PO}_{4}{ }^{3-}-\mathrm{P}$ in the filtered porewater were analysed using a flow injection analyser (Skalar Analytical SAN ${ }^{++}$, Netherlands).

\subsubsection{Nutrient fluxes across the SWI}

Triplicate sediment samples $(0-15 \mathrm{~cm})$ from each pond were used in an incubation experiment to study nutrient fluxes across the SWI. The incubation device (Fig. 2) was constructed according to Cowan et al. (1996) and Chen et al. (2014). Approximately 15 cm-long sediment cores were retrieved, along with $15 \mathrm{~cm}$ deep of overlying water. Bottom water samples at each site were also taken and stored under the same conditions as the incubated cores. The sediment cores were covered using a Teflon plunger with inlet and outlet tubes, and sealed to the core cylinder with an O-ring. The overlying water above the sediments was bubbled with air to simulate the in situ bottom water $\mathrm{O}_{2}$ levels (Mu et al., 2017). Thereafter, the cores were incubated in a temperature-regulated incubator device (QHZ-98A, China) for a period of $9 \mathrm{~h}$. The incubated temperature was chosen to be the same as the field in situ temperature. Based on previous researches (Yang et al., 2017a) and the pilot experiments of this study, we selected shaking velocities of the incubator to be 20,40 , and $80 \mathrm{rpm}$, to simulate the intensity of shrimp disturbance during the initial, middle, and final stages, respectively. Sampling of overlying water was performed using a plastic syringe at the beginning and the end of the $9 \mathrm{~h}$ incubation period. During each sampling, $60 \mathrm{~mL}$ of overlying water was taken and then replaced by $60 \mathrm{~mL}$ of overlying water collected in situ in the field. Water samples were filtered through $0.45 \mu \mathrm{m}$ acetate fibre membranes immediately and the nutrient concentrations were measured with a flow injection analyser (Skalar 
Analytical SAN ${ }^{++}$, Netherlands). Fluxes of nutrients across the SWI were quantified according to the following equation (Cheng et al., 2015):

$$
F=\left(C_{\mathrm{W}-\mathrm{E}}-C_{\mathrm{W}-\mathrm{B}}\right) \times V / S / T
$$

203 where $F\left(\mathrm{mg} \mathrm{m}^{-2} \mathrm{~h}^{-1}\right)$ is the flux of nutrient at the SWI (positive and negative values 204 indicate a net release from, and a net uptake by the sediment, respectively); $C_{\mathrm{W}-\mathrm{E}}$ and $205 C_{\mathrm{W}-\mathrm{B}}$ are the nutrient concentration $\left(\mathrm{mg} \mathrm{L}^{-1}\right)$ in the overlying water at the end and the 206 beginning of incubation, respectively; $V$ is the volume of overlying water (L); $S$ is the 207 cross-sectional area of the sediment column $\left(\mathrm{m}^{2}\right)$; and $T$ is the incubation time $(\mathrm{h})$.

\subsection{Collection and analysis of adjacent coastal waters of the study area}

In order to evaluate the impact of shrimp pond effluent on the water quality of receiving coastal waters, surface water samples $(10 \mathrm{~cm}$ depth) were collected from adjacent coastal waters of the study area (Fig. 1) both before and after the discharge of

212 shrimp pond effluents upon the completion of shrimp harvesting. Sampling was carried 213 out between 09:00 and 10:30 by boat in sequence from site 1 to site 6 (Fig. 1). At each 214 sampling site, one water sample at a depth of $10 \mathrm{~cm}$ was collected by a $5 \mathrm{~L}$ Niskin bottle. Water samples were then stored in $500 \mathrm{ml}$ polyethylene bottles kept at $4{ }^{\circ} \mathrm{C}$, transported to the laboratory, and analysed within $72 \mathrm{~h}$. Water samples were filtered 217 and analyzed for dissolved inorganic nutrients following the same method as 218 previously described. The unfiltered seawater samples were also analyzed for the concentrations of total nitrogen (TN) and total phosphorus (TP) by the peroxodisulfate oxidation method (Ebina et al., 1983), with the $\mathrm{NO}_{3}{ }^{-}-\mathrm{N}$ and $\mathrm{PO}_{4}{ }^{3-}-\mathrm{P}$ concentrations in

221 the digestate being determined by ion chromatograph (Dionex 2100, American) (Han et 222 al., 2014). Detection limits for TN and TP were 0.7 and $0.3 \mu \mathrm{mol} \mathrm{L}{ }^{-1}$, respectively. The 223 relative standard deviations of these analyses were in the range $2-5 \%$.

\section{2.5. Statistical analyses}


The calculations of basic statistical parameters (e.g. mean, standard error (SE), etc.) were carried out using Microsoft Excel 2003. Differences in the studied variables among the three growth stages of shrimps were assessed by analysis of variance

228 (ANOVA). Pearson correlation analysis was conducted to examine the relationships 229 between nutrient fluxes/levels and the environmental variables. All data were reported 230 as mean \pm 1 SE. ANOVA and correlation analysis were carried out using SPSS 231 (Version 17.0) with the significance level set at 0.05.

\section{Results and discussions}

\subsection{Physicochemical and biological properties of the shrimp ponds}

The measured physicochemical variables and shrimp biomass in the three shrimp ponds are presented in Table 3. The water and sediment temperatures over the study period ranged between 24.02 and $30.95^{\circ} \mathrm{C}$, and 22.49 and $28.16^{\circ} \mathrm{C}$, respectively, with significantly higher temperatures during the middle stage (Table 3). Water $\mathrm{pH}$ varied significantly among the three growth stages $(p<0.05)$, with considerably lower values during the middle stage (Table 3). Both sediment TN content and porosity were significantly higher during the middle stage than the other two stages, which was

241 similar to the temperature trend (Table 3). Water DO level and shrimp biomass also 242 varied significantly $(p<0.05)$ among the growth stages, with the highest and lowest 243 values during the final and initial stages, respectively (Table 3).

244 The results of Chl $a$ concentrations in the water column are presented in Fig. 3. 245 Average Chl $a$ concentrations ranged between $130.1 \pm 2.5$ and $258.3 \pm 3.1 \mu \mathrm{g} \mathrm{L}^{-1}$ during 246 the study period. Significant temporal variations in Chl $a$ were observed, with 247 considerably lower concentrations observed during the initial stage than the other two 248 stages (Fig. 3). However, no significant difference in Chl $a$ concentration was seen 249 among the three water depths ( $p>0.05$; Fig. 3). 


\subsection{Nutrient concentrations in the water column}

The results of dissolved inorganic nutrients in the water column are shown in Fig. 4. The $\mathrm{NO}_{2}{ }^{-}-\mathrm{N}, \mathrm{NO}_{3}{ }^{-}-\mathrm{N}$, and $\mathrm{NH}_{4}{ }^{+}-\mathrm{N}$ concentrations during the study period ranged between 7.18 and $49.75 \mu \mathrm{g} \mathrm{L}{ }^{-1}, 15.66$ and $81.02 \mu \mathrm{g} \mathrm{L} \mathrm{L}^{-1}$, and 0.10 and $0.81 \mathrm{mg} \mathrm{L}^{-1}$, respectively, with mean values of $21.45 \pm 1.47 \mu \mathrm{g} \mathrm{L}{ }^{-1}, 56.47 \pm 2.24 \mu \mathrm{g} \mathrm{L}^{-1}$, and $0.44 \pm 0.02$ mg L ${ }^{-1}$, respectively. The mean concentration of $\mathrm{NH}_{4}{ }^{+}-\mathrm{N}$ was significantly higher than that of $\mathrm{NO}_{2}{ }^{-}-\mathrm{N}$ and $\mathrm{NO}_{3}{ }^{-}-\mathrm{N}(p<0.05)$, which showed that $\mathrm{NH}_{4}{ }^{+}-\mathrm{N}$ was the predominant species of DIN in the water column of shrimp ponds. Our findings were inconsistent with those of Silva et al. (2013) and Li et al. (2014), in which $\mathrm{NO}_{3}^{-}-\mathrm{N}$ was the dominant form of DIN in a super-intensive biofloc technology culture system and the semi-intensive shrimp ponds, respectively. The high $\mathrm{NH}_{4}{ }^{+}-\mathrm{N}$ concentrations in the water column observed in this study might be attributed to the high rates of $\mathrm{NH}_{4}{ }^{+}-\mathrm{N}$ release from the shrimp pond sediment.

Significant temporal variations in $\mathrm{NO}_{\mathrm{x}}{ }^{-}-\mathrm{N}$ and $\mathrm{NH}_{4}{ }^{+}-\mathrm{N}$ concentrations in the water column of shrimp ponds were observed over the study period (Fig. 4). The $\mathrm{NO}_{\mathrm{x}}{ }^{-}-\mathrm{N}$ concentrations in the pond water showed an increasing trend over time (Fig. 4a, b). A plausible reason for this could be due to the continuous input of protein-rich feeds that had stimulated the degradation of organic matter and nitrification, thereby favouring the accumulation of $\mathrm{NO}_{\mathrm{x}}{ }^{-}-\mathrm{N}$ in the water column. In contrast to $\mathrm{NO}_{\mathrm{x}}{ }^{-}-\mathrm{N}$, we found lower $\mathrm{NH}_{4}{ }^{+}-\mathrm{N}$ concentrations during the final stage but higher concentrations during the middle stage (Fig. 4c). These temporal patterns were different from those seen in other results in which $\mathrm{NH}_{4}{ }^{+}-\mathrm{N}$ concentrations in aquaculture systems generally increased over time in response to an increase in shrimp excretion rates and the accumulation of residual feeds (Yu et al., 2013; Castillo-Soriano et al., 2013). In our study, the significantly higher water temperature (Table 3) during the middle stage 
could have stimulated microbial mineralization of organic matter (Hopkinson et al., 2001; Zhang et al., 2013) and hence the release of $\mathrm{NH}_{4}{ }^{+}-\mathrm{N}$ from the sediment into the overlying water. On the other hand, the significantly lower $\mathrm{NH}_{4}{ }^{+}-\mathrm{N}$ concentrations

278 detected during the final stage might, to some extent, be explained by a combination of 279 low water temperature (Table 3) and high consumption rate of $\mathrm{NH}_{4}{ }^{+}-\mathrm{N}$ by 280 phytoplankton (as represented by Chl a) (Fig. 3).

281 Dissolved $\mathrm{PO}_{4}{ }^{3-}-\mathrm{P}$ concentrations in the water column also differed significantly 282 among the three stages, ranging between 36.12 and $99.55 \mu \mathrm{g} \mathrm{L}^{-1}$ (Fig. 4d). In contrast to 283 DIN, the $\mathrm{PO}_{4}{ }^{3-}-\mathrm{P}$ concentrations in pond water showed a decreasing trend over the 284 study period (Fig. 3d). Some previous researches have indicated that, $\mathrm{P}$ assimilation in 285 aquaculture production system is tightly linked to biomass growth (Montoya et al., 286 2000; Mai et al., 2010). Furthermore, Hu et al. (2015) found that the high 287 phytoplankton amount accounted for the low $\mathrm{PO}_{4}{ }^{3-}-\mathrm{P}$ concentrations in the coastal 288 upwelling ecosystem of the southern Taiwan Strait. Hence, the decrease in $\mathrm{PO}_{4}{ }^{3-}-\mathrm{P}$ 289 concentrations in the water column of our shrimp ponds over time (Fig. 4d) was 290 probably associated with an increase in the assimilation of $\mathrm{P}$ by shrimps and 291 phytoplankton. This was further supported by the observation that both shrimp biomass 292 and Chl $a$ were negatively correlated with $\mathrm{PO}_{4}{ }^{3-}-\mathrm{P}$ concentrations in the water column 293 over time (Table 3, Figs. 2 and 3d).

\subsection{Nutrient concentrations in the sediment porewater}

295 The results of dissolved inorganic nutrients in the sediment porewater of the 296 shrimp ponds are presented in Fig. 5. The $\mathrm{NO}_{2}^{-}-\mathrm{N}, \mathrm{NO}_{3}^{-}-\mathrm{N}, \mathrm{NH}_{4}{ }^{+}-\mathrm{N}$, and $\mathrm{PO}_{4}{ }^{3-}-\mathrm{P}$ 297 concentrations in the sediment porewater over the study period ranged between 36.57 298 and $108.10 \mu \mathrm{g} \mathrm{L}^{-1}, 30.00$ and $384.10 \mu \mathrm{g} \mathrm{L}^{-1}, 4.82$ and $24.95 \mathrm{mg} \mathrm{L}^{-1}$, and 0.28 and 0.88 $299 \mathrm{mg} \mathrm{L} \mathrm{L}^{-1}$, respectively, with mean values of $75.66 \pm 5.02 \mu \mathrm{g} \mathrm{L}^{-1}, 158.41 \pm 21.15 \mu \mathrm{g} \mathrm{L} \mathrm{L}^{-1}$, 

by $\mathrm{NH}_{4}{ }^{+}-\mathrm{N}$ as indicated by the low $\mathrm{NO}_{\mathrm{x}}{ }^{-}-\mathrm{N}$ and high $\mathrm{NH}_{4}{ }^{+}-\mathrm{N}$ concentrations (Fig. 5), which was similar to the case of the water column. This could be attributed to the highly reducting environment in the sediment that favoured the presence of $\mathrm{NH}_{4}{ }^{+}-\mathrm{N}$ over the oxidized forms of nitrogen (Zhang et al., 2013).

A significant difference in dissolved inorganic nutrient concentrations was recorded across the three shrimp growth stages during the study period (Fig. 5). The concentrations of $\mathrm{NO}_{\mathrm{x}}{ }^{-}-\mathrm{N}$ and $\mathrm{PO}_{4}{ }^{3-}-\mathrm{P}$ showed similar temporal patterns, with lower and higher values during the initial and final stages, respectively (Fig. 5). The nutrients in porewater are typically assumed to be derived from the degradation of organic matter

310 (Lee et al., 2008; Zhang et al., 2013). A large supply of organic matter may ensure a 311 steady supply of substrates for microbial mineralization of soil $\mathrm{N}$ and P (Kristensen et 312 al., 2008), leading to an overall increase in porewater nutrient concentrations. Hence, 313 the increase in porewater $\mathrm{NO}_{\mathrm{x}}{ }^{-}-\mathrm{N}$ and $\mathrm{PO}_{4}{ }^{3-}-\mathrm{P}$ concentrations observed in the present 314 study over time (Fig. 5a, 5b, and 5d) was probably associated with an increase in the 315 accumulation of degradable organic matter in sediment (Jackson et al., 2003; Lacoste and Gaertner-Mazouni, 2016; Matos et al., 2016).

317 The porewater $\mathrm{NH}_{4}{ }^{+}-\mathrm{N}$ concentrations demonstrated a different temporal trend 318 from those of $\mathrm{NO}_{\mathrm{x}}{ }^{-}-\mathrm{N}$ and $\mathrm{PO}_{4}{ }^{3-}-\mathrm{P}$, with the highest values being observed during the 319 middle stage than the final stage (Fig. 5c). This temporal pattern was consistent with 320 that of temperature and TN content in the pond sediment $(p<0.01$; Fig. 6). These results 321 further supported the idea that both high sediment temperature and great supply of 322 organic matter contributed to the elevated porewater $\mathrm{NH}_{4}{ }^{+}-\mathrm{N}$ concentration found 323 during the middle stage as compared to the initial stage. Meanwhile, at the final stage, 324 the low porewater $\mathrm{NH}_{4}{ }^{+}-\mathrm{N}$ concentration could be attributed to the combination of low 
sediment temperature and intense bioturbation, which enhanced nitrification through increasing the oxygen levels in the sediment (Henriksen et al., 1983). This hypothesis could be further supported by the higher porewater $\mathrm{NO}_{\mathrm{x}}{ }^{-}-\mathrm{N}$ concentration observed in

328 our ponds during the final stage (Fig. 5a and 5b).

\subsection{Fluxes of nutrients across the sediment-water interface}

The results of our laboratory incubation experiment on the fluxes of dissolved inorganic nutrients across the SWI are shown in Fig. 7. The $\mathrm{NO}_{\mathrm{x}}{ }^{-}-\mathrm{N}$ fluxes were quite variable over the study period, ranging from negative values $\left(-0.20\right.$ and $-0.84 \mathrm{mg} \mathrm{m}^{-2} \mathrm{~h}^{-1}$ for $\mathrm{NO}_{2}^{-}-\mathrm{N}$ and for $\mathrm{NO}_{3}^{-}-\mathrm{N}$, respectively) during the initial stage to positive values ( 0.76 and $1.57 \mathrm{mg} \mathrm{m}^{-2} \mathrm{~h}^{-1}$ for $\mathrm{NO}_{2}{ }^{-}-\mathrm{N}$ and $\mathrm{NO}_{3}{ }^{-}-\mathrm{N}$, respectively) during the final stage (Fig. 7a and 7b). In contrast, the $\mathrm{NH}_{4}{ }^{+}-\mathrm{N}$ and $\mathrm{PO}_{4}{ }^{3-}-\mathrm{P}$ fluxes across the SWI were always positive, which corresponded to net nutrient releases from the sediment to the water column (Fig. 7c and 7d). The $\mathrm{NH}_{4}{ }^{+}-\mathrm{N}$ and $\mathrm{PO}_{4}{ }^{3-}-\mathrm{P}$ fluxes over the study period ranged between 10.17 and $140.86 \mathrm{mg} \mathrm{m}^{-2} \mathrm{~h}^{-1}$, and 0.25 to $14.84 \mathrm{mg} \mathrm{m}^{-2} \mathrm{~h}^{-1}$, respectively, with average values of $41.42 \pm 6.69$ and $2.74 \pm 0.71 \mathrm{mg} \mathrm{m}^{-2} \mathrm{~h}^{-1}$, respectively. These results show that $\mathrm{NH}_{4}{ }^{+}-\mathrm{N}$ was the main form of DIN being released from the sediment to the water column, while the magnitude of DIN fluxes was higher than that of $\mathrm{PO}_{4}{ }^{3-}-\mathrm{P}$

Fig. 7 also shows that DIN fluxes from the shrimp pond sediment varied significantly among the three stages, which was in agreement with the results reported in other aquaculture systems (e.g. Nizzoli et al., 2011; Holmer et al., 2015; Zhong et al., 2015; Yang et al., 2017a). Many of these studies suggested that sediment temperature, organic matter content, DO, and benthic organisms were the dominant factors governing the temporal variations of nutrient fluxes across the SWI. In this study, $\mathrm{NO}_{\mathrm{x}}{ }^{-}-\mathrm{N}$ fluxes were positively correlated with shrimp biomass (Table 4). An increase 
in shrimp biomass might imply a greater bioturbation of sediment by shrimps, which

351 could enhance the oxygen supply from the overlying water to the sediment (Henriksen

352 et al., 1983), and subsequently increase nitrification rates (Nicholaus and Zheng, 2014;

353 Zhong et al., 2015) and the release of $\mathrm{NO}_{\mathrm{x}}{ }^{-}-\mathrm{N}$ from the pond sediment over time (Fig.

354 7a and 7b). This hypothesis was further supported by the strong correlation observed

355 between $\mathrm{NO}_{\mathrm{x}}{ }^{-}-\mathrm{N}$ and DO concentrations (Table 4). In addition, Jiang et al. (2000) and

356 Zhong et al. (2015) reported that the excretion of Litopenaeus vannamei could enrich

357 the sediments and contributed to the enhancement of $\mathrm{NO}_{\mathrm{x}}{ }^{-}-\mathrm{N}$ release from the sediment.

358 The positive relationship between $\mathrm{NO}_{\mathrm{x}}{ }^{-}-\mathrm{N}$ fluxes and shrimp biomass found in this

359 study suggested that the temporal dynamics of $\mathrm{NO}_{\mathrm{x}}{ }^{-}-\mathrm{N}$ could at least partly be

360 associated with the excretion of urea and other nitrogenous compounds from shrimps.

361 On the other hand, previous studies have suggested that the enhancement of $\mathrm{NH}_{4}{ }^{+}-\mathrm{N}$

362 release across the SWI could be attributed primarily to animal excretion, bioturbation,

363 and the transport of accumulated $\mathrm{NH}_{4}{ }^{+}-\mathrm{N}$ in the anoxic sediment (Svensson,1997;

364 Zhang et al., 2011a, b; Zhong et al., 2015). In the present study, the temporal patterns of

365 sediment temperature, $\mathrm{TN}$ content, and $\mathrm{NH}_{4}{ }^{+}-\mathrm{N}$ fluxes in the shrimp ponds were highly

366 similar (Table 3 and Fig. 7c), which implied that the effects of temperature on the

367 mineralization rates of organic matter were more significant than that of shrimp

368 excretion or other environmental variables. Moreover, the temporal change in the rate

369 of $\mathrm{NH}_{4}{ }^{+}-\mathrm{N}$ release across the SWI was similar to that of shrimp biomass from the initial

370 to the middle stage (Fig. 7c and Table 3), indicating that the influence of shrimp

371 excretion and bioturbation was also important in controlling the variations of $\mathrm{NH}_{4}{ }^{+}-\mathrm{N}$

372 flux over time during the initial and middle stages of shrimp growth.

$373 \mathrm{PO}_{4}{ }^{3-}-\mathrm{P}$ fluxes across the SWI of shrimp ponds also greatly varied among different

374 stages, with minimum and maximum fluxes occurred at the initial and final stages, 
respectively (Fig. 7d). Similar temporal patterns were observed by Nicholaus and Zheng (2014), who found a significant increase in $\mathrm{PO}_{4}{ }^{3-}$-P fluxes across the SWI over time for clam aquaculture ponds. Zhong et al. (2015) also reported similar temporal variations of $\mathrm{PO}_{4}{ }^{3-}-\mathrm{P}$ fluxes from the aquaculture ponds of Litopenaeus vannamei. These studies found that bioturbation played a primary role in controlling the rate of $\mathrm{PO}_{4}{ }^{3-}-\mathrm{P}$ release from the aquaculture ponds. Waldbusser et al. (2004) reported that the effects of bioturbation on $\mathrm{PO}_{4}{ }^{3-}$-P release could be attributed to the changes in oxygen level and sediment redox potential. Nicholaus and Zheng (2014) further proposed that bioturbation could influence $\mathrm{PO}_{4}{ }^{3-}-\mathrm{P}$ release through altering the bacterial decomposition of biodeposits and the resuspension of sediments. In the present study, we found that $\mathrm{PO}_{4}{ }^{3-}$-P fluxes were significantly and positively correlated with shrimp biomass ( $r^{2}=0.657, p<0.001, n=27$ ), which pointed to the potential of shrimp bioturbation on sediment $\mathrm{PO}_{4}{ }^{3-}-\mathrm{P}$ fluxes. Yet, as $\mathrm{PO}_{4}{ }^{3-}-\mathrm{P}$ fluxes in this study were determined based on laboratory incubation experiments only, in situ measurements might be needed to quantify $\mathrm{PO}_{4}{ }^{3-}-\mathrm{P}$ fluxes in a field setting simulating the actual conditions, and the exact mechanisms of bioturbation effects on $\mathrm{PO}_{4}{ }^{3-}-\mathrm{P}$ release deserve further investigation.

\subsection{Impact of biogeochemical cycling of nutrients}

\subsubsection{Impact of sediment nutrient release on the survival rates of shrimp}

We observed the emergence of shrimp diseases in the ponds of our study area, with a mass mortality of shrimps particularly during the middle and late stages of shrimp growth. The shrimp survival rates in the three ponds ranged between 60 and $70 \%$ (personal communication), with a mean value of $65 \%$ that was significantly lower than the normal level of $80 \%$ (Lai, 2014). The low survival rates of shrimps in our ponds might be related to the high rates of sediment nutrient release. Over the study 
period, we observed predominantly positive $\mathrm{NO}_{\mathrm{x}}{ }^{-} \mathrm{N}$ fluxes, and consistently positive

$401 \mathrm{NH}_{4}{ }^{+}-\mathrm{N}$ and $\mathrm{PO}_{4}{ }^{3-}-\mathrm{P}$ fluxes across the SWI in the coastal shrimp ponds (Fig. 7), 402 indicating that the shrimp pond sediment was generally a net source of dissolved 403 inorganic nutrients. We found that the rates of nutrient (especially $\mathrm{NH}_{4}{ }^{+}-\mathrm{N}$ and $\mathrm{PO}_{4}{ }^{3-}-\mathrm{P}$ ) 404 release from the shrimp pond sediment were much higher than those reported by Yang 405 et al. (2017a) from the estuarine and marine sediments in various aquaculture systems 406 (e.g. blue crab, grouper, tuna, oysters) in China. The nutrient fluxes from our shrimp 407 pond sediment were also much greater than those from the pearl oyster culture in 408 Tuamotu Archipelago (Lacoste and Gaertner-Mazouni, 2016), mussel cultures (Mytilus 409 edulis) in Skive Fjord of Denmark (Holmer et al., 2015), and shrimp (L. vannamei) 410 ponds in Shandong Province of China (Zhong et al., 2015). In particular, the sediment $411 \mathrm{NH}_{4}{ }^{+}-\mathrm{N}$ fluxes in our shrimp ponds were significant higher than the range of 412 0.01-31.25 $\mathrm{mg} \mathrm{N} \mathrm{m}^{-2} \mathrm{~h}^{-1}$ reported for a range of freshwater, estuarine, and marine 413 sediments in aquaculture ponds by Hargreaves (1998). The large release of $\mathrm{NH}_{4}{ }^{+}-\mathrm{N}$ 414 from sediment could lead to significant ammonia accumulation in the water column, 415 which would subsequently be oxidized to nitrites $\left(\mathrm{NO}_{2}^{-}\right)$by nitrite bacteria under oxic 416 conditions (Kou et al., 2014). Generally, the acceptable or safe levels for nitrite and 417 ammonia in prawn aquaculture systems under low-salinity water conditions are under $41810 \mu \mathrm{g} \mathrm{L}^{-1}$ and $0.20 \mathrm{mg} \mathrm{L}^{-1}$, respectively (Lai, 2014). Yet, the mean $\mathrm{NO}_{2}{ }^{-}-\mathrm{N}$ and $\mathrm{NH}_{4}{ }^{+}-\mathrm{N}$ 419 concentrations from the shrimp ponds water in Min River estuary were $21.45 \pm 1.47 \mu \mathrm{g}$ $420 \mathrm{~L}^{-1}$ and $0.44 \pm 0.02 \mathrm{mg} \mathrm{L}^{-1}$, respectively, which were substantially greater than the 421 acceptable levels. This could impose toxicity problems to shrimps, leading to a 422 reduction in both survival and growth rates, as well as an increase in a variety of 423 physiological dysfunctions of shrimps (Hu et al., 2012; Kou et al., 2014). 
The low survival rates of shrimp were also probably related to the interactions of large sediment nutrient releases and harmful algal blooms. In the present study, high rates of sediment nutrient release to the overlying water might support a significant proportion of the total nutrient requirements for primary productivity in shrimp ponds, which in turn lead to the formation of harmful algal or cyanobacterial blooms. It has long been known that cyanobacterial blooms in aquaculture ponds can cause acute and massive shrimp deaths (Alonso-Rodrıguez and Páez-Osuna, 2003; Ajinet al., 2016; Gao et al., 2017). The stoichiometric ratio of $\mathrm{N}$ and $\mathrm{P}$ plays an important role in determining the dominant phytoplankton species and the potential formation of harmful algal blooms in the water column of shrimp ponds (Alonso-Rodrıguez and Páez-Osuna, 2003). In the Gulf of California, Barraza-Guzmán (1994) found that a N/P ratio of 6.8 in shrimp pond waters would favor the dominance of cyanobacteria over diatoms, dinoflagellates and phytoflagellates. In the present study, the molar ratios of $\mathrm{DIN} / \mathrm{PO}_{4}{ }^{3-}-\mathrm{P}$ of our shrimp ponds water were estimated to be $4.49 \pm 0.79,11.30 \pm 2.11$, and $6.43 \pm 1.13$ during the initial, middle, and final stages, respectively. The overall mean N/P ratio in this study was $7.41 \pm 0.98$, which was close to that reported by Barraza-Guzmán (1994), which implied that cyanobacteria was dominant in our study ponds that caused an adverse effect on shrimp growth.

\subsubsection{Impact of aquaculture pond effluent on water quality of receiving coastal waters}

We further estimated the effects of effluent discharge from the shrimp ponds on the adjacent coastal water column, by comparing the nutrient levels in the coastal waters of the study area (Shanyutan wetland) before and after the discharge of shrimp pond effluents following harvesting (Table 5). Based on an estimated total area of 234 ha and an average depth of $1.4 \mathrm{~m}$ for aquaculture ponds in this region, we calculated that a total of $3.3 \times 10^{6} \mathrm{~m}^{3}$ of effluents were released from the ponds into the adjacent 
waters without any prior treatment on an annual basis. As shown in Table 5, following

450 the discharge of shrimp pond effluents, the nutrient levels in the coastal waters around

451 the study area changed dramatically. The $\mathrm{NO}_{\mathrm{x}}{ }^{-}-\mathrm{N}, \mathrm{NH}_{4}{ }^{+}-\mathrm{N}, \mathrm{TN}, \mathrm{PO}_{4}{ }^{3-}-\mathrm{P}$, and $\mathrm{TP}$

452 concentrations in the adjacent receiving coastal waters of the study area increased 453 significantly by $350 \%, 146 \%, 270 \%, 415 \%$, and $234 \%$, respectively, following the 454 discharge of pond effluents. Our results suggested that the traditional practice of annual 455 drainage of shrimp ponds could potentially increase the nutrient levels of the receiving waters in the surrounding area within a relatively short time period.

Previous studies have shown that the export of aquaculture pond effluents is an important anthropogenic source of nutrient pollution in the coastal areas (Seitzinger et al., 2005; Cardoso-Mohedano et al., 2016a). Lacerda et al. (2008) estimated that a total of $827 \mathrm{t} \mathrm{N} \mathrm{yr}^{-1}$ of nitrogen and $69.2 \mathrm{t} \mathrm{P} \mathrm{yr}^{-1}$ of phosphorus were exported by aquaculture production from shrimp ponds with an area of 3,279 ha in the Ceará State coast of northeastern Brazil. In the Gulf of California, the nutrient loads from shrimp aquaculture were $9044 \mathrm{t} \mathrm{N} \mathrm{yr}^{-1}$ and and $3078 \mathrm{t} \mathrm{P} \mathrm{yr}^{-1}$, which were estimated with a mass balance model assuming an export of $110.2 \mathrm{~kg} \mathrm{~N}$ and $37.5 \mathrm{~kg} \mathrm{P} \mathrm{yr}^{-1} \mathrm{ha}^{-1}$, and a total area of 82,068 ha of shrimp farms (Páez-Osuna et al. 1997; 2013; 2017). On the other hand, the inputs of nitrogen and phosphorus from shrimp aquaculture was estimated to be $1.5 \%$ and $0.9 \%$ of the main sources from municipal and agricultural activities, 468 respectively (Páez-Osuna et al. 1999). In the Mekong Delta, De Silva et al. (2010) 469 estimated a discharge of 31,602 t of $\mathrm{N}$ and 9,893 $\mathrm{t}$ of $\mathrm{P}$ from a pond-based striped 470 catfish production system with an area of 7000 ha. In this study, we estimated that the 471 discharges of TN and TP arising from shrimp aquaculture (1639 ha for area and $1.4 \mathrm{~m}$ 472 for water depth) into the adjacent seawater of the Min River estuary in 2015 were 30.45 $473 \mathrm{t}$ and $2.40 \mathrm{t}$, respectively. Assuming that our data are representative of the aquaculture 
474

475

ponds across China with a total area of $2.57 \times 10^{6}$ ha and a mean water depth of $1.4 \mathrm{~m}$, we calculated that approximately $4.77 \times 10^{4} \mathrm{t} \mathrm{N} \mathrm{y}^{-1}$ and $3.75 \times 10^{3} \mathrm{t} \mathrm{P} \mathrm{y}^{-1}$ were exported from the direct discharge of mariculture pond effluents into the adjacent seawater in China. This represents about $5 \%$ of the total nutrient loadings from the main rivers of China into the sea (State Oceanic Administration, People’s Republic of China, 2015). Given that the estimated contribution of industrial and municipal sewages to the nutrient loadings in the coastal sea is $32 \%$ and $41 \%$, respectively (State Oceanic Administration, People’s Republic of China, 2015), the total nutrient loading from the effluent discharge of aquaculture ponds is rather small in comparison with other anthropogenic nutrient sources. Yet, aquaculture production might still be an important contributor to the problem of water pollution locally in the coastal areas of China, leading to potential negative effects (e.g. cause eutrophication, red tides, and biodiversity loss) on the adjacent coastal ecosystems (Herbeck et al., 2013; Cardoso-Mohedano et al., 2016a; Páez-Osuna et al., 2017). Long-term field monitoring and sampling with multiple frequencies in various regions of China should be carried out in future in order to obtain a better and more precise picture on the influence of aquaculture pond effluent on coastal ecosystems.

\section{Conclusions}

Based on the analysis of the samples collected from the sediment and water column at three representative shrimp ponds in the Min River estuary at three growth stages over the production cycle, we made some key findings on the biogeochemical cycling of nutrients in the mariculture ponds of China as follows:

1) $\mathrm{NH}_{4}{ }^{+}-\mathrm{N}$ was the main form of DIN in both the water column and sediment porewater. Also, the concentrations of DIN were significant higher than those of $\mathrm{PO}_{4}{ }^{3-}-\mathrm{P}$, which implied that P could become a limiting nutrient to phytoplankton growth in the shrimp 
ponds.

500 2) Nutrient (DIN and $\mathrm{PO}_{4}{ }^{3-}$-P) fluxes across the sediment-water interface of shrimp 501 ponds greatly varied among the different growth stages of shrimps, with considerably 502 higher values during the middle and late stages. These results suggested that water 503 quality deterioration caused by high rates of sediment nutrient releases could 504 potentially lead to mass mortality of shrimps during the middle and late stages. 3) The discharge of aquaculture pond effluents could be an important contributor to the problem of water pollution and eutrophication in the receiving waters of the coastal

507 zones in China. Effective treatment of aquaculture pond effluents before discharge will 508 become an important challenge in the future in alleviating the pressures of 509 eutrophication in the coastal zone.

\section{Acknowledgements}

511 This research was financially supported by the National Science Foundation of China (No. 512 41671088), the Study-Abroad Grant Project for Graduates of the School of Geographical Sciences, 513 and the Graduated Student Science and Technology Innovation Project of the School of 514 Geographical Science, Fujian Normal University (GY201601). D. Bastviken was funded by the 515 Swedish Council VR, Linköping University, and the European Research Council ERC (grant no. 516 725546). We would like to thank Wei-Ning Du and Jing-Yu Zhang of the School of Geographical 517 Sciences, Fujian Normal University, for their field assistance. We would like to thank Yun-Chang 518 Yao, Chun-Ying Ren and Zong-Ming Wang of the Northeast Institute of Geography and 519 Agroecology, Chinese Academy of Sciences, for their provides geographic data. We sincerely thank 520 the reviewers and editor for their valuable comments.

\section{References}

523 Ajin, A.M., Silvester, R., Alexander, D.M.N., Abdulla, M.H., 2016. Characterization of blooming algae and 524 bloom-associated changes in the water quality parameters of traditional pokkali cum prawn fields along the South West coast of India. Environ. Monit. Assess. 188,145. 
Alonso-Rodriguez, R., Páez-Osuna, F., 2003. Nutrients, phytoplankton and harmful algal blooms in shrimp ponds: a review with special reference to the situation in the Gulf of California. Aquaculture 219, 317-336.

Barraza-Guzmán, I., 1994. Evaluación cuantitativa y cualitativa del fitoplancton en dos sistemas de cultivo de camarón, sistemas semi-intensivo e intensivo en Sinaloa, México. Tesis Profesional. Esc. Ciencias del Mar, Univ. Autón. Sin., México, 65 pp. (in Spanish).

Burford, M.A., Glibert, P.M., 1999. Short-term nitrogen uptake and regeneration in early and late growth phase shrimp ponds. Aquac. Res. 30(3), 215-227.

Burford, M.A., Costanzo, S.D., Dennison, W.C., Jackson, C.J., Jones, A.B., McKinnon, A.D., Preston, N.P., Trott, L.A., 2003. A synthesis of dominant ecological processes in intensive shrimp ponds and adjacent coastal environments in NE Australia. Mar. Pollut. Bull. 46, 1456-1469.

Cardoso-Mohedano, J.G., Páez-Osuna, F., Amezcua-Martínez, F., Ruiz-Fernández, A.C., Ramírez-Reséndiz, G., Sánchez-Cabeza, J.A., 2016a. Combined environmental stress from shrimp farm and dredging releases in a subtropical coastal lagoon (SE Gulf of California). Mar. Pollut. Bull. 104, 83-91.

Cardoso-Mohedano, J.G., Bernardello, R., Sanchez-Cabeza, J.A., Páez-Osuna, F., Ruiz-Fernández, A.C., Molino-Minero-Re, E., Cruzado, A., 2016b. Reducing nutrient impacts from shrimp effluents in a subtropical coastal lagoon. Sci. Total Environ. 571, 388-397.

Casillas-Hernández, R., Mgallón-Barajas, F., Portillo-Clarck, G., Páez-Osuna, F., 2006. Nutrient mass balances in semi-intensive shrimp ponds from Sonora, Mexico using two feeding strategies: trays and mechanical dispersal. Aquaculture 258, 289-298.

Castillo-Soriano, F.A., Ibarra-Junquera, V., Escalante-Minakata, P., Mendoza-Cano, O., Ornelas-Paz, J.de J., Almanza-Ramírez, J.C., Meyer-Willerer, A.O., 2013. Nitrogen dynamics model in zero water exchange, low salinity intensive ponds of white shrimp, Litopenaeus vannamei, at Colima, Mexico. Lat. Am. J. Aquat. Res., 41(1), 68-79.

Chen, Z.H., Chen, N.W., Wu, Y.Q., Mo, Q.L., Zhou, X.P., Lu, T., Tian, Y., 2014. Sediment-water flux and processes of nutrients and gaseous nitrogen release in a China river reservoir. Environ. Sci. 35(9), 3325-3335 (in

Chen,Y., Dong, S.L., Wang, F., Gao, Q.F., Tian, X.L., 2016. Carbon dioxide and methane fluxes from feeding and no-feeding mariculture ponds. Environ. Pollut. 212, 489-497. nitrogen exchange across the sediment-water interface in the eastern Chongming tidal flat of the Yangtze Estuary. Environ. Earth. Sci. 74(3): 2173-2184. 

Chesapeake Bay: Seasonal patterns, controlling factors and ecological significance. Estuaries 19(3), 562-580.

David, S.E., Chattopadhyay, M., Chattopadhyay, S., Jennerjahn, T.C., 2016. Impact of human interventions on nutrient biogeochemistry in the Pamba River, Kerala, India. Sci. Total Environ. 541,1420-1430.

De Silva, S.S., Ingram, B.A., Nguyen, P.T., Bui, T.M., Gooley, G.J., Turchini, G.M., 2010. Estimation of nitrogen and phosphorus in effluent from the striped catfish farming sector in the Mekong Delta, Vietnam. Ambio 39, 504-514.

De Vittor, C., Faganeli, J., Emili, A., Covelli, S., Predonzani, S., Acquavita, A., 2012. Benthic fluxes of oxygen, carbon and nutrients in the Marano and Grado Lagoon (northern Adriatic Sea, Italy). Estuar. Coast. Shelf S. 113, 57-70.

Ebina, J., Tsutsui, T., Shirai, T., 1983. Simultaneous determination of total nitrogen and total phosphorus in water using peroxodisulfate oxidation. Water Res. 17(12), 1721-1726.

Elser, J.J., Bracken, M.E.S., Cleland, E.E., Gruner, D.S., Harpole, W.S., Hillebrand, H., Ngai, J.T., Seabloom, E.W., Shurin, J.B., Smith, J.E., 2007. Global analysis of nitrogen and phosphorus limitation of primary producers in

FAO. 2016. The State of World Fisheries and Aquaculture 2016. Contributing to food security and nutrition for all. Rome, 200 pp.

Gao, J.F., Zuo, H.L., Yang, L.W., He, J.H., Niu, S.W., Weng, S.P., He, J.G., Xu, X.P., 2017. Long-term influence of cyanobacterial bloom on the immune system of Litopenaeus vannamei. Fish Shellfish Immun. 61, 79-85.

Guerrero-Galván, S.R., Páez-Osuna, F., Ruiz-Fernández, A.C, Espinoza-Angulo, R., 1999. Seasonal variation in the water quality and chlorophyll $a$ of semi-intensive shrimp ponds in a subtropical environment. Hydrobiologia 391, 33-45.

Han, H.J., Lu, X.X., Burger, D.F., Joshi, U.M., Zhang, L., 2014. Nitrogen dynamics at the sediment-water interface in a tropical reservoir. Ecol. Eng. 73, 146-153.

Hargreaves, J.A., 1998. Nitrogen biogeochemistry of aquaculture ponds. Aquaculture 166(3), 181-212. sediments based on biogeochemical indicators. Mar. Pollut. Bull. 56, 810-824. the sediment and fluxes of ammonium and nitrate to the overlaying water. Ecol. Bull. 35, 193-205. and fish ponds causing eutrophication in coastal and back-reef waters of NE Hainan, tropical China. Cont. Shelf Res. 57, 92-104. 
Holmer, M., Thorsen, S.W., Carlsson, M.S., Kjerulf, P.J., 2015. Pelagic and benthic nutrient regeneration processes in mussel cultures (Mytilus edulis) in a eutrophic coastal area (Skive Fjord, Denmark). Estuar. Coast. 38, 1629-1641. http://dx.doi.org/10.1007/s12237-014-9864-8.

Hopkinson Jr., C.S., Giblin, A.E., Tucker, J., 2001. Benthic metabolism and nutrient regeneration on the continental shelf of Eastern Massachusetts, USA. Mar. Ecol. Prog. Ser. 224, 1-19.

Huang, S.L., Wu, M., Zang, C.J., Du ,S.L., Domagalski, J., Gajewska, M., Gao, F., Lin, C., Guo, Y., Liu, B.Y., Wang, S.M., Luo, Y., Szymkiewicz, A., Szymkiewicz, R., 2016. Dynamics of algae growth and nutrients in experimental enclosures culturing bighead carp and common carp: Phosphorus dynamics. Int. J. Sediment Res. $31,173-180$.

Hu, J., Lan, W.L., Huang, B.Q., Chiang, Q.P., Hong, H.S., 2015. Low nutrient and high chlorophyll a coastal upwelling system-A case study in the southern Taiwan Strait. Estuar. Coast. Shelf S. 166, 170-177.

Hu, Z., Lee, J.W., Chandran, K., Kim, S., Sharma, K., Khanal, S.K., 2014. Influence of carbohydrate addition on nitrogen transformations and greenhouse gas emissions of intensive aquaculture system. Sci. Total Environ. 470-471, 193-200.

Hu, Z., Lee, J.W., Chandran, K., Kim, S., Khanal, S.K., 2012. Nitrous oxide $\left(\mathrm{N}_{2} \mathrm{O}\right)$ emission from aquaculture: a review. Environ. Sci. Technol. 46, 6470-6480.

Jackson, C., Preston, N., Thompson, P.J., Burford, M., 2003. Nitrogen budget and effluent nitrogen components at an intensive shrimp farm. Aquaculture, 218(1), 397-411.

Jiang, D.H., Lawrence, A.L., Neill, W.H., Gong, H., 2000. Effects of temperature and salinity on nitrogenous excretion by Litopenaeus vannamei juveniles. J. Exp. Mar. Biol. Ecol .253(2), 193-209.

Kiemer, M.C.B., Black, K.D., Lussot, D., Bullock, A.M., Ezzi, I., 1995. The effects of chronic and acute exposure to hydrogen sulphide on Atlantic salmon (Salmo salar L.). Aquaculture 135(4), 311-327.

Kou, H.Y., Xian, J.A., Guo, H., Qian, K., Miao, Y.T., Ye, C.X., Pan, X.B., Wang, A.L., 2014. Research progress of toxic effects of nitrite on shrimp. Mar. Sci. 2014, 38(2), 107-115(in Chinese).

Kristensen, E., Bouillon, S., Dittmar, T., Marchand, C., 2008. Organic carbon dynamics in mangrove ecosystems: a review. Aquat. Bot. 2, 201-219.

Krom, M.D., Berner, R.A., 1980. The diffusion coefficients of sulphate, ammonium and phosphate in anoxic marine sediments. Limnol. Oceanogr. 25, 327-337.

Lacerda, L.D., Mussi-Molisani, M., Sena, D., Parente-Mai, L., 2008. Estimating the importance of natural and anthropogenic sources on $\mathrm{N}$ and P emission to estuaries along the Ceará state coast NE Brazil. Environ. Monit. Assess. 141, 149-164.

Lacoste, É., Gaertner-Mazouni, N., 2016. Nutrient regeneration in the water column and at the sediment-water interface in pearl oyster culture (Pinctada margaritifera) in a deep atoll lagoon (Ahe, French Polynesia). Estuar. Coast. Shelf S. 182, 304-309. 

minimizing the detrimental effects of $\mathrm{H}_{2} \mathrm{~S}$ in freshwater aquaculture systems. Aquaculture 238(1-4), 263-281.

Lai, S.Y., 2014. The Ecological Aquaculture Technique of Prawn. China Agriculture Press, Beijing (in Chinese).

Lee, R.Y., Porubsky, W.P., Feller, I.C., McKee, K.L., Joye, S.B., 2008. Porewater biogeochemistry and soil metabolism in dwarf red mangrove habitats (Twin Cays, Belize). Biogeochemistry 87, 181-198.

Li, R.H., Liu, S.M., Li, Y.W., Zhang, G.L., Ren, J.L., Zhang, J., 2014. Nutrient dynamics in tropical rivers, lagoons, and coastal ecosystems of eastern Hainan Island, South China Sea. Biogeosciences 11, 481-506.

Liu, S.W., Hu, Z.Q., Wu, S., Li, S.Q., Li, Z.F., Zou, J.W., 2015. Methane and nitrous oxide emissions reduced following conversion of rice paddies to inland crab-fish aquaculture in southeast China. Environ. Sci. Technol. 50(2), 633-642.

Mai, H., Fotedar, R., Fewtrell, J., 2010. Evaluation of Sargassum sp. as a nutrient-sink in an integrated seaweed-prawn (ISP) culture system. Aquaculture 310, 91-98.

Matos, C.R.L. Mendoza, U., Diaz, R., Moreira, M., Belem, A.L., Metzger, E., Albuquerque, A.L.S., Machado, W.,

Molnar, N., Welsh, D.T., Marchand, C., Deborde, J., Meziane, Tarik., 2013. Impacts of shrimp farm effluent on water quality, benthic metabolism and N-dynamics in a mangrove forest (New Caledonia). Estuar. Coast. Shelf S. $117,12-21$.

Montoya, R.A., Lawrence, A.L., Grant, W.E., Velasco, M., 2000. Simulation of phosphorus dynamics in an intensive shrimp culture system: effects of feed formulations and feeding strategies. Ecol. Model. 129, 131-142.

Mu, D., Yuan, D.K., Feng, H., Xing, F.W., Teo, F.Y., Li, S.Z., 2017. Nutrient fluxes across sediment-water interface in Bohai Bay Coastal Zone, China. Mar. Pollut. Bull. 114 (2), 705-714. http://dx.doi.org/10.1016/j.marpolbul.2016.10.056.

Nicholaus, R., Zheng, Z.M., 2014. The effects of bioturbation by the Venus clam Cyclina sinensis on the fluxes of nutrients across the sediment-water interface in aquaculture ponds. Aquacult. Int. 22, 913-924.

Nizzoli, D., Welsh, D.T., Viaroli, P., 2011. Seasonal nitrogen and phosphorus dynamics during benthic clam and suspended mussel cultivation. Mar. Pollut. Bull. 62, 1276-1287.

Páez-Osuna, F., Álvarez-Borrego, S., Ruiz-Fernández, A.C., García-Hernández, J., Jara-Marini, M.E., Bergés-Tiznado, M.E., Piñón-Gimate, A., Alonso-Rodríguez, R., Soto-Jiménez, M.F., Frías-Espericueta, M.G., Ruelas-Inzunza, J., Green-Ruiz, C.R, Osuna-Martínez, C.C., Sánchez-Cabeza, J.A., 2017. Environmental status 290-297. 
Páez-Osuna, F., Guerrero-Galván, S.R., Ruiz-Fernández, A.C., 1999. Discharge of nutrients from shrimp farming to the Gulf of California. Mar. Pollut. Bull. 38, 585-592.

Páez-Osuna, F., Piñón-Gimate, A., Ochoa-Izaguirre, M.J., Ruiz-Fernández, A.C., Ramírez-Reséndiz, G., Alonso-Rodríguez, R., 2013. Dominance patterns in macroalgal and phytoplankton biomass under different nutrient loads in subtropical coastal lagoons from SE Gulf of California. Mar. Pollut. Bull. 77, 274-281.

Sahu, B.C., Adhikari, S., Mahapatra, A.S., Dey, L., 2013. Carbon, nitrogen, and phosphorus budget in scampi (Macrobrachium rosenbergii) culture ponds. Environ. Monit. Assess. 185(12), 10157-10166.

Sajana, T.K., Ghangrekar, M.M., Mitra, A., 2013. Application of sediment microbial fuel cell for in situ reclamation of aquaculture pond water quality. Aquacult. Eng. 57, 101-107.

State Oceanic Administration, People’s Republic of China. 2015. Bulletin of China’s Marine Environmental Status $\begin{array}{lllll}\text { of } & \text { China } & \text { Yor } & \text { Yo }\end{array}$ <http://www.coi.gov.cn/gongbao/nrhuanjing/nr2015/201604/t20160414_33872.html>.

Seitzinger, S.P., Harrison, J.A., Dumont, E., Beusen, A.H.W., Bouwman, A.F., 2005. Sources and delivery of carbon, nitrogen, and phosphorus to the coastal zone: An overview of Global Nutrient Export from Watersheds (NEWS) models and their application. Glob. Biogeochem. Cycles 19(4), http://dx.doi.org/10.1029/2005GB002606.

Svensson, J.M., 1997. Influence of Chironomus plumosus larvae on ammonium flux and denitrification (measured by the acetylene blockage-and the isotope pairing-technique) in eutrophic lake sediment. Hydrobiologia 346(1-3), 157-168.

Silva, K.R., Wasielesky Jr., W., Abreu, P.C., 2013. Nitrogen and phosphorus dynamics in the biofloc production of the Pacific white shrimp, Litopenaeus vannamei. J. Word Aquacult. Soc. 44(1), 30-41.

Su, Y.P., Ma, S., Tian, X.L., Dong, S.L., 2009. An experimental study on nitrogen, phosphorus and carbon budgets in intensive pond of shrimp Fenneropenaeus chinensis. South China Fish. Sci. 5(6), 54-58. (in Chinese with English abstract).

Tong, C., Wang, W.Q., Zeng, C.S., Marrs, R., 2010. Methane emissions from a tidal marsh in the Min River estuary, southeast China. J. Environ. Sci. Heal. A. 45, 506-516.

Wahab, M.A., Bergheim, A., Braaten, B., 2003. Water quality and partial mass budget in extensive shrimp ponds in Bangladesh. Aquaculture, 218(1), 413-423.

Waldbusser, G.G., Marinelli, R.L., Whitlatch, R.B., Visscher, P.T., 2004. The effects of infaunal biodiversity on biogeochemistry of coastal marine sediments. Limnol. Oceanogr. 49(5), 1482-1492.

Wang, W.Q., Wang, M., 2007. The Mangroves of China. Science Press, Beijing.

Wolanski, E., Spagnol, S., Thomas, S., Moore, K., Alongi, D.M., Trott, L., Davidson, A., 2000. Modelling and visualizing the fate of shrimp pond effluents in a mangrove-fringed tidal creek. Estuar. Coast. Shelf S. 50, 85-97. 
Wu, H., Peng, R., Yang, Y., He, L., Wang, W.Q., Zheng, T.L., Lin, G.H., 2014. Mariculture pond influence on mangrove areas in south China: Significantly larger nitrogen and phosphorus loadings from sediment wash-out than from tidal water exchange. Aquaculture 2014, 426, 204-212.

Yang, P., He, Q.H., Huang, J.F., Tong, C., 2015. Fluxes of greenhouse gases at two different aquaculture ponds in the coastal zone of southeastern China. Atmos. Environ. 115, 269-277.

Yang, P., Jin, B.S., Tan, L.S., Tong, C., 2017a. Temporal variation of nutrients fluxes across the sediment-water interface of shrimp ponds and influencing factors in the Jiulong River Estuary. Acta Ecol. Sin. 37(1), 192-203. (in Chinese)

Yang, P., Lai, D.Y.F., Huang, J.F., Tong, C., 2017b. Effect of drainage on $\mathrm{CO}_{2}$, $\mathrm{CH}_{4}$, and $\mathrm{N}_{2} \mathrm{O}$ fluxes from aquaculture ponds during winter in a subtropical estuary of China. J. Environ. Sci. 2017, http://dx.doi.org/10.1016/j.jes.2017.03.024.

Yu, H.B., Gao, Q.F., Sun, Y.J., Dong, S.L., Fu, X.J., 2013. Dynamic change and circulation of nutrients in polyculture system of sea cucumber (Apostichopus japonicus) and shrimp (Fenneropenaeus chinensis). Period. Ocean. Univ. China 43(9), 25-32 (in Chinese).

Zhang, Z.D., Wang, F., Dong, S.L., 2011a. A preliminary study on structural optimization in polycultural systems of Ctenopharyngodon idellus with Hypophthalmichthys molitrix and Litopenaeus vannamei. Period. Ocean. Univ. China Z2 (in Chinese).

Zhang, L., Shen, Q., Hu, H., 2011b. Impacts of Corbicula fluminea on oxygen uptake and nutrient fluxes across the sediment-water interface. Water Air Soil Pollut. 220(1-4), 399-411.

Zhang, L., Wang, L., Yin, K.D., Lü, Y., Zhang, D.R., Yang, Y.Q., Huang, X.P., 2013. Pore water nutrient characteristics and the fluxes across the sediment in the Pearl River estuary and adjacent waters, China. Estuar. Coast. Shelf S. 133, 182-192.

Zhang, Y., Waang, Y.J., Wang, Y.Q., Liu D.Y., 2016. Spatial distribution and correlation of environmental factors and chlorophyll a concentrations in the Bohai Sea during the summer of 2013. Mar. Sci. Bull. 35(5), 571-578. (in Chinese)

Zhong, D.S., Wang, F., Dong, S.L., Li, L., 2015. Impact of Litopenaeus vannamei bioturbation on nitrogen dynamics and benthic fluxes at the sediment-water interface in pond aquaculture. Aquacult. Int. 2015, 23(4): 967-980.

Zhou, X.P., Chen, N.W., Yan, Z.H., Duan, S.W., 2016. Warming increases nutrient mobilization and gaseous nitrogen removal from sediments across cascade reservoirs. Environ. Poll. 219, 490-500. http://dx.doi.org/10.1016/j.envpol.2016.05.060. 
Table 1

2 Basic details of the three shrimp ponds in the Min River estuary

\begin{tabular}{|c|c|c|c|}
\hline & Pond-1 & Pond-2 & Pond-3 \\
\hline Shrimp species & Litopenaeus vannamei & Litopenaeus vannamei & Litopenaeus vannamei \\
\hline Mean water depth (m) & 1.3 & 1.5 & 1.5 \\
\hline Surface area (ha) & 0.85 & 0.70 & 0.72 \\
\hline Stocking density $\left(\mathrm{PL} \mathrm{m} \mathrm{m}^{-2}\right)^{\mathrm{a}}$ & 35 & 45 & 45 \\
\hline Survival rate $(\%)^{a}$ & 62 & 63 & 70 \\
\hline Yield (kg pond $\left.{ }^{-1} \operatorname{crop}^{-1}\right)^{\mathrm{a}}$ & 2300 & 2500 & 3000 \\
\hline Feed conversion rate ${ }^{b}$ & 1.72 & 1.30 & 1.11 \\
\hline
\end{tabular}

3 a The data for the stocking density, survival rate, and yield were provided by the farmers.

$4 \quad{ }^{\mathbf{b}}$ Feed conversion rate $=$ dry weight of feeds added/wet weight of shrimps produced 
Table 2

6 The three main stages of the grow-out cycle during the aquaculture period in intensive shrimp 7 ponds in the Min River estuary

\begin{tabular}{|c|c|c|}
\hline Stage & Duration (days) & Remarks $^{\text {a }}$ \\
\hline Initial stage & $0-47$ & $\begin{array}{l}\text { Pond filled, fertilized and stocked. Feeding rate } 10-16 \mathrm{~kg} \mathrm{ha}^{-1} \mathrm{~d}^{-1} \text {. } \\
\text { Water depth } 1.0-1.1 \mathrm{~m} \text {. Water salinity } 3.0 \% \text { - } 3.6 \% \text {. Shrimp weight } \\
0.01-2.43 \mathrm{~g} \mathrm{PL}^{-1} \text {. }\end{array}$ \\
\hline Middle stage & $48-114$ & $\begin{array}{l}\text { Feeding rate } 50-55 \mathrm{~kg} \mathrm{ha}^{-1} \mathrm{~d}^{-1} \text {. Water depth } 1.4-1.5 \mathrm{~m} \text {. Water salinity } \\
2.2 \%-2.7 \% \text {. Shrimp weight } 2.43-9.67 \mathrm{~g} \mathrm{PL}^{-1} \text {. }\end{array}$ \\
\hline Final stage & $115-163$ (or more) & $\begin{array}{l}\text { Harvest, and effluent discharge. Feeding rate } 40-45 \mathrm{~kg} \mathrm{ha}^{-1} \mathrm{~d}^{-1} \text {. Water } \\
\text { depth } 1.2-1.3 \mathrm{~m} \text {. Water salinity } 1.7 \% \text { - } 2.0 \% \text {. Shrimp weight } 9.67- \\
13.25 \mathrm{~g} \mathrm{PL}^{-1} \text {. }\end{array}$ \\
\hline
\end{tabular}

8

a The data for the feeding rate, shrimp weight and water salinity were provided by the farmers. 
Table 3

10 Physicochemical and biological properties in the shrimp ponds of the Min River estuary during the 11 study period.

\begin{tabular}{llll}
\hline & Initial stage & Middle stage & Final stage \\
\hline Water physicochemical properties* & & & \\
$\quad$ Temperature $\left({ }^{\circ} \mathrm{C}\right)$ & $24.02 \pm 0.02 \mathbf{b}$ & $30.95 \pm 0.18 \mathbf{a}$ & $24.17 \pm 0.10 \mathbf{b}$ \\
Dissolved oxygen $\left(\mathrm{mg} \mathrm{L}^{-1}\right)$ & $8.31 \pm 0.17 \mathbf{b}$ & $11.88 \pm 0.61 \mathbf{a}$ & $12.39 \pm 0.37 \mathbf{a}$ \\
$\mathrm{pH}$ & $8.95 \pm 0.02 \mathbf{c}$ & $8.64 \pm 0.04 \mathbf{b}$ & $10.00 \pm 0.03 \mathbf{a}$ \\
Sediment physicochemical properties** & & & \\
$\quad$ Temperature $\left({ }^{\circ} \mathrm{C}\right)$ & $22.49 \pm 0.03 \mathbf{b}$ & $28.16 \pm 0.12 \mathbf{a}$ & $22.52 \pm 0.22 \mathbf{b}$ \\
$\quad$ Total nitrogen $\left(\mathrm{g} \mathrm{kg}{ }^{-1}\right)$ & $1.70 \pm 0.08 \mathbf{b}$ & $2.03 \pm 0.10 \mathbf{a}$ & $1.86 \pm 0.11 \mathrm{ab}$ \\
$\quad$ Porosity $(\%)$ & $61.02 \pm 2.18 \mathbf{b}$ & $83.25 \pm 8.24 \mathbf{a}$ & $75.31 \pm 4.78 \mathbf{a}$ \\
Biological parameters & & & \\
$\quad$ Shrimp biomass $\left(\mathrm{g} \mathrm{shrimp}{ }^{-1}\right)$ & $0.92 \pm 0.01 \mathbf{c}$ & $7.01 \pm 0.06 \mathbf{b}$ & $12.30 \pm 0.11 \mathbf{a}$ \\
\hline
\end{tabular}

* Values are means $( \pm$ S.E.) of water samples $(n=108)$ collected at three depths, at four sampling times $(08: 00$,

$1311: 00,14: 00,17: 00 \mathrm{~h})$ and in three ponds for each stage. $* *$ Values are means $( \pm$ S.E.) of sediment samples $(n=9)$

14 collected from three ponds for each stage. Mean values in a row with the same lowercase letter are not significantly different by the Fischer's Least Significant Difference (LSD) test $(p<0.05)$. 


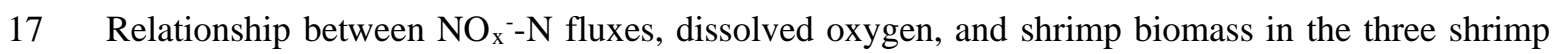

18 ponds.

\begin{tabular}{llllll}
\hline Nutrients fluxes $(\boldsymbol{y})$ & Variables $(\boldsymbol{x})$ & Regression equation & $\boldsymbol{r}^{2}$ & Correlation coefficient & $\boldsymbol{n}$ \\
\hline $\mathrm{NO}_{2}-\mathrm{N}$ fluxes & Dissolved oxygen & $y=0.0866 \mathrm{x}-0.7249$ & 0.6993 & $0.836^{* *}$ & 27 \\
& Shrimp biomass & $y=0.0427 x-0.1393$ & 0.6480 & $0.805^{* *}$ & 27 \\
$\mathrm{NO}_{3}-\mathrm{N}$ fluxes & Dissolved oxygen & $y=0.2043 x-1.9428$ & 0.6314 & $0.795^{* *}$ & 27 \\
& Shrimp biomass & $y=0.1145 x-0.6545$ & 0.7565 & $0.870^{* *}$ & 27 \\
\hline
\end{tabular}

$19 * *$ denote correlation coefficients for significant relationships at the 0.01 level. 
Table 5

21 Nutrient concentrations in adjacent the coastal waters of the study area before and after the

22 discharge of shrimp pond effluents during the low tide after the completion of shrimp harvesting.

\begin{tabular}{llllll}
\hline & $\mathbf{N O}_{\mathbf{x}}{ }^{-}-\mathbf{N}\left(\boldsymbol{\mu g ~ ~ ^ { - 1 }}\right)$ & $\mathbf{N H}_{4}{ }^{+}-\mathbf{N}\left(\mathbf{m g ~ L}^{-1}\right)$ & $\mathbf{T N}\left(\mathbf{m g ~ L}^{-1}\right)$ & $\mathbf{P O}{ }^{3-}-\mathbf{P}\left(\mathbf{m g ~ L}^{-1}\right)$ & $\mathbf{T P}\left(\mathbf{m g ~ L}^{-1}\right)$ \\
\hline Before & $119.36 \pm 6.91 \mathrm{a}$ & $0.81 \pm 0.16 \mathrm{a}$ & $0.84 \pm 0.15 \mathrm{a}$ & $0.14 \pm 0.03 \mathrm{a}$ & $0.31 \pm 0.07 \mathrm{a}$ \\
After & $418.33 \pm 29.97 \mathrm{~b}$ & $1.19 \pm 0.18 \mathrm{~b}$ & $2.27 \pm 0.14 \mathrm{~b}$ & $0.58 \pm 0.10 \mathrm{~b}$ & $0.72 \pm 0.15 \mathrm{~b}$ \\
\hline
\end{tabular}

23 Values are means $( \pm$ S.E.) of samples $(n=6)$ collected from adjacent coastal waters of the shrimp ponds. Mean

24 values in a column with the same lowercase letter are not significantly different by the independent-samples t-test $25 \quad(p<0.05)$. 


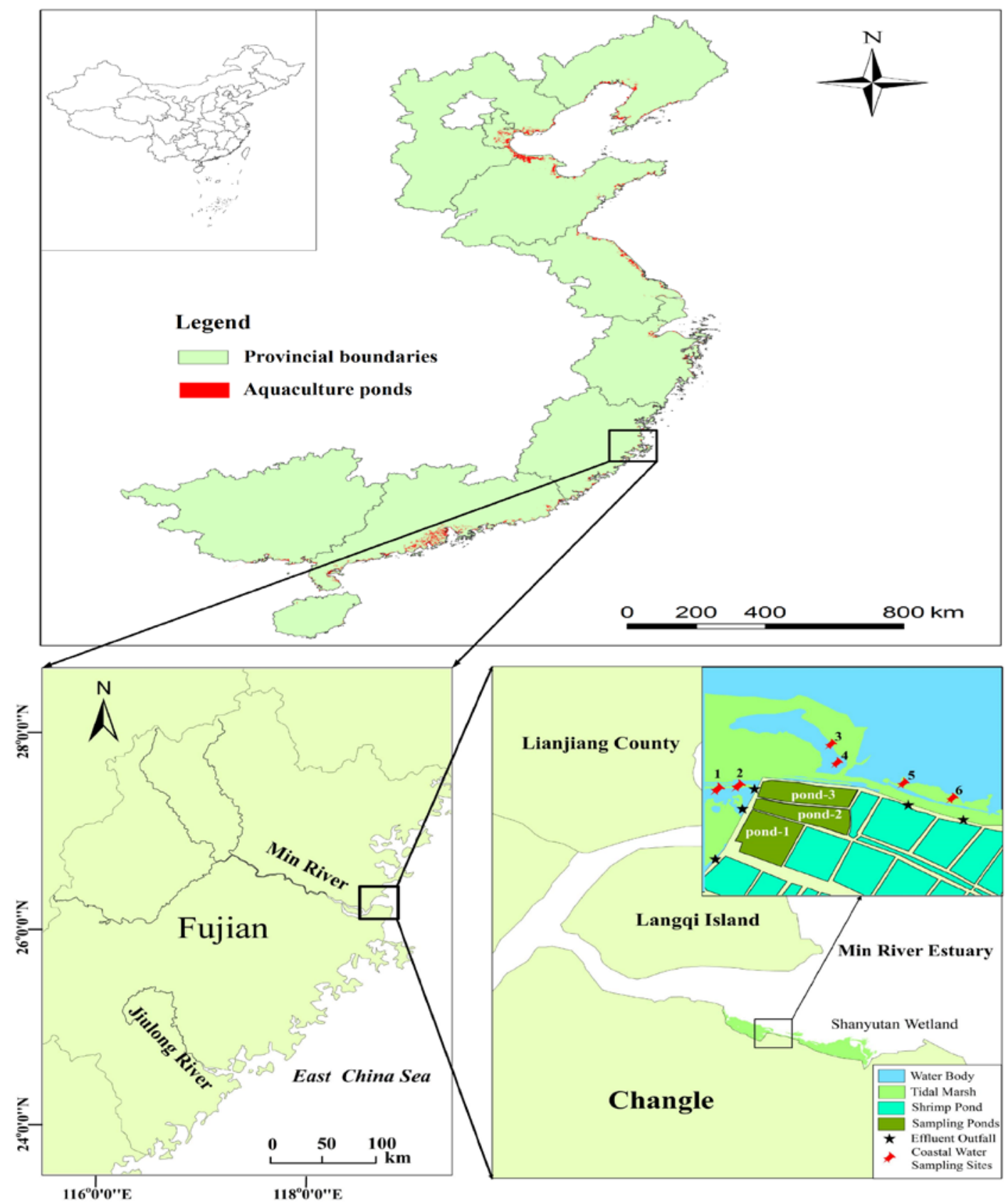

2 Fig. 1. The locations of sampling sites in the aquaculture shrimp ponds in the central 3 and western parts of the Min River estuary. 


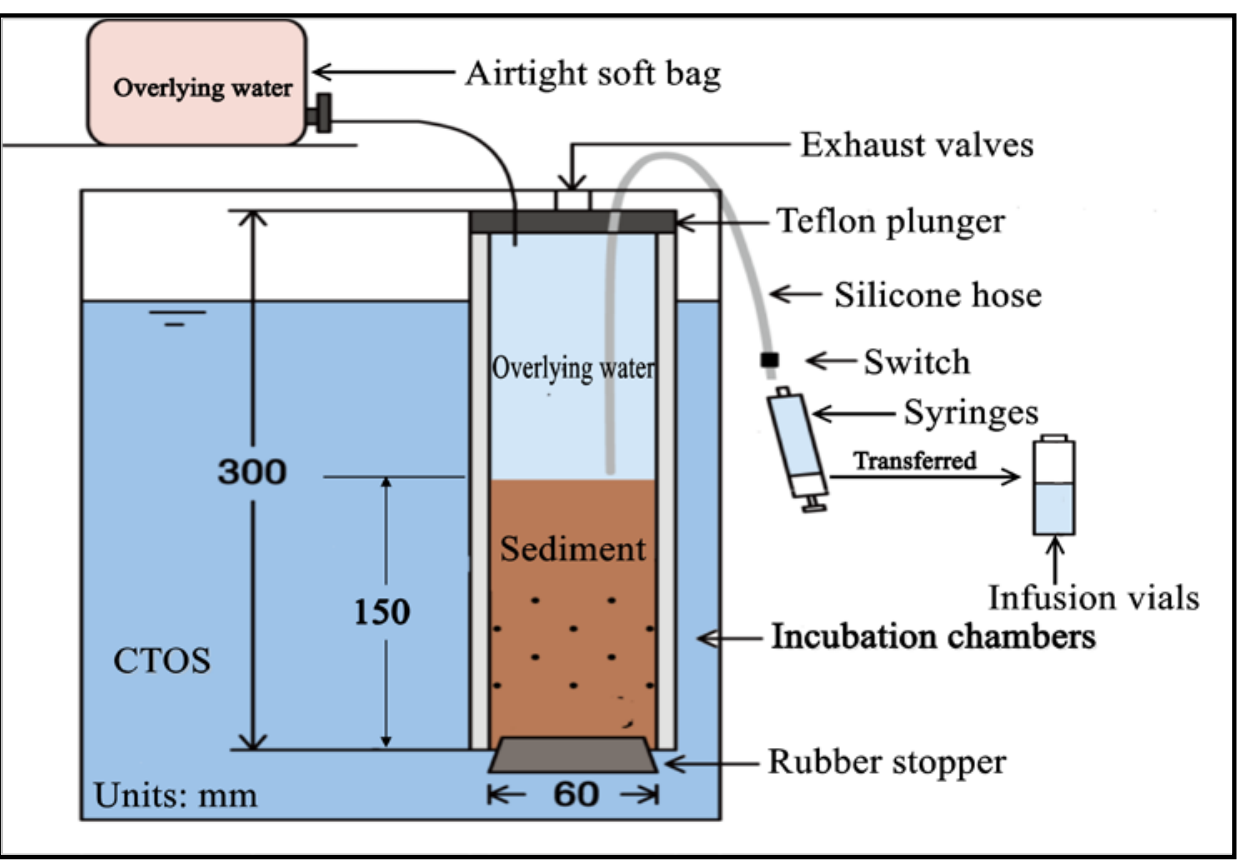

6 Fig. 2. Conceptual diagram of the incubation device used for determining nutrient

7 fluxes across the sediment-water interface (Modified according to Chen et al., 2014).

8 CTOS in the figure represent constant temperature oscillation incubator. 


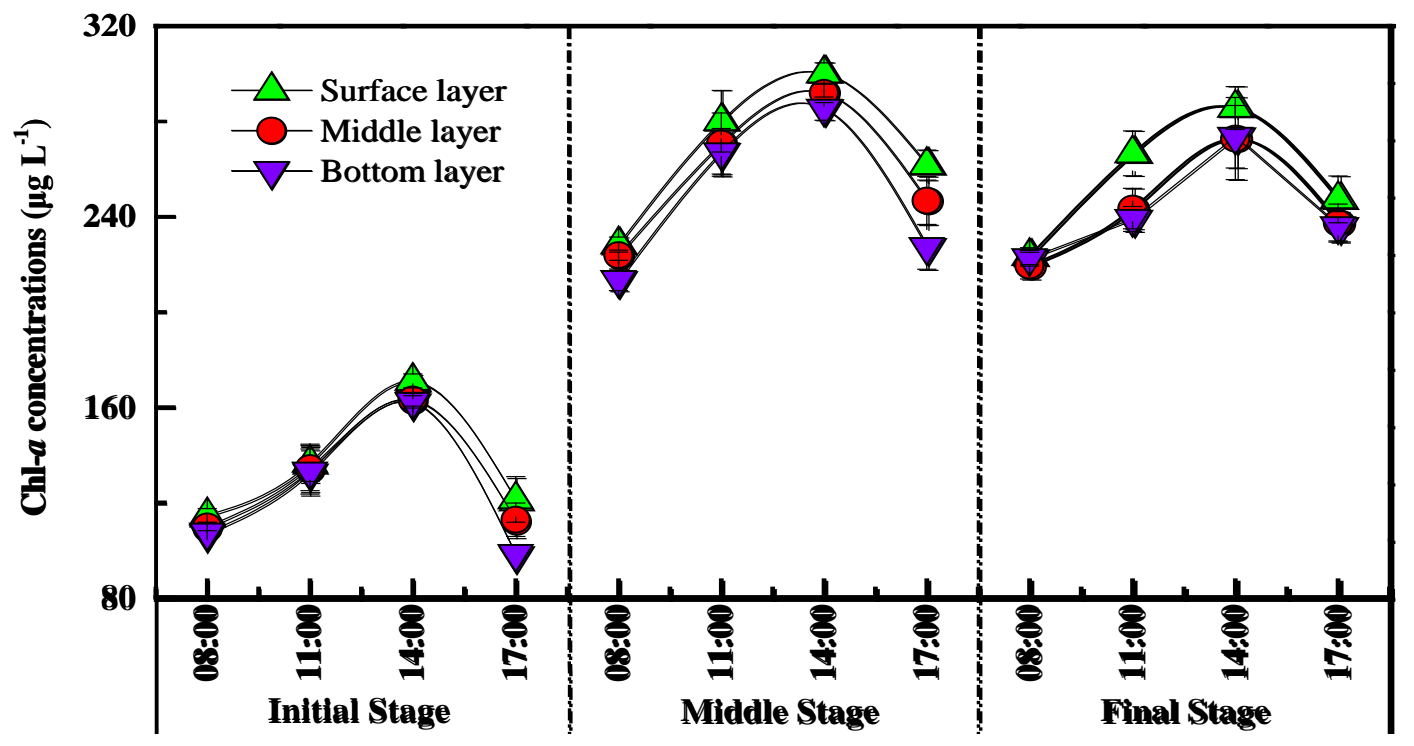

10 Fig. 3. Temporal variations of chlorophyll $a(\mathrm{Chl}-a)$ concentrations in the water column

11 of shrimp ponds at the Min River estuary. Bars represent mean $\pm \operatorname{SE}(n=9)$. 

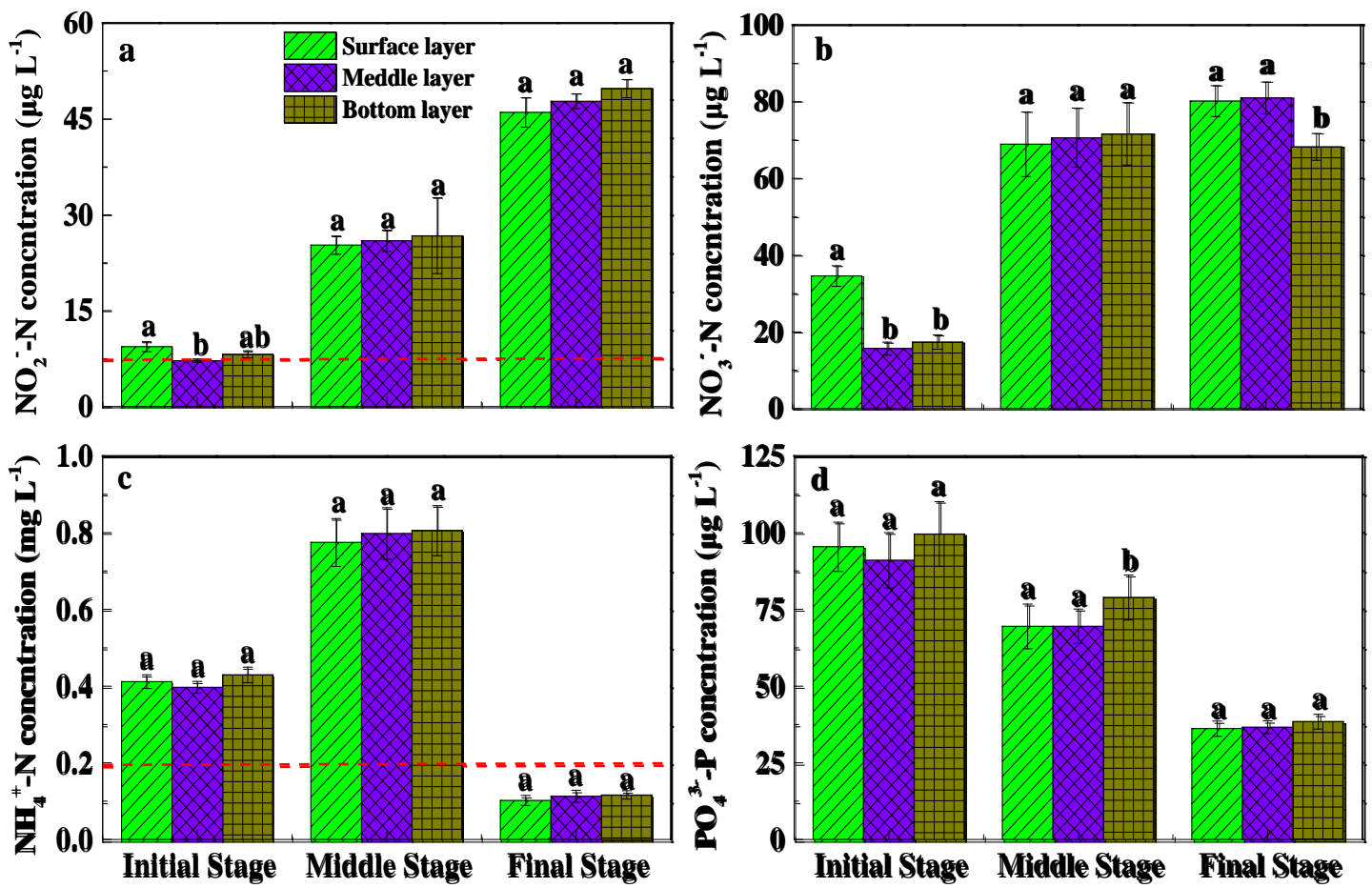

Fig. 4. Temporal variations of nutrient concentrations in the water column of shrimp

14 ponds at the Min River estuary. Bars represent mean \pm SE $(n=36)$. Different lowercase

15 letters above the bars indicate significant differences at the $p<0.05$ level among

16 sampling depths at each stage. The red dashed line indicates the safe levels for

17 ammonia and nitrite in the shrimp ponds. 

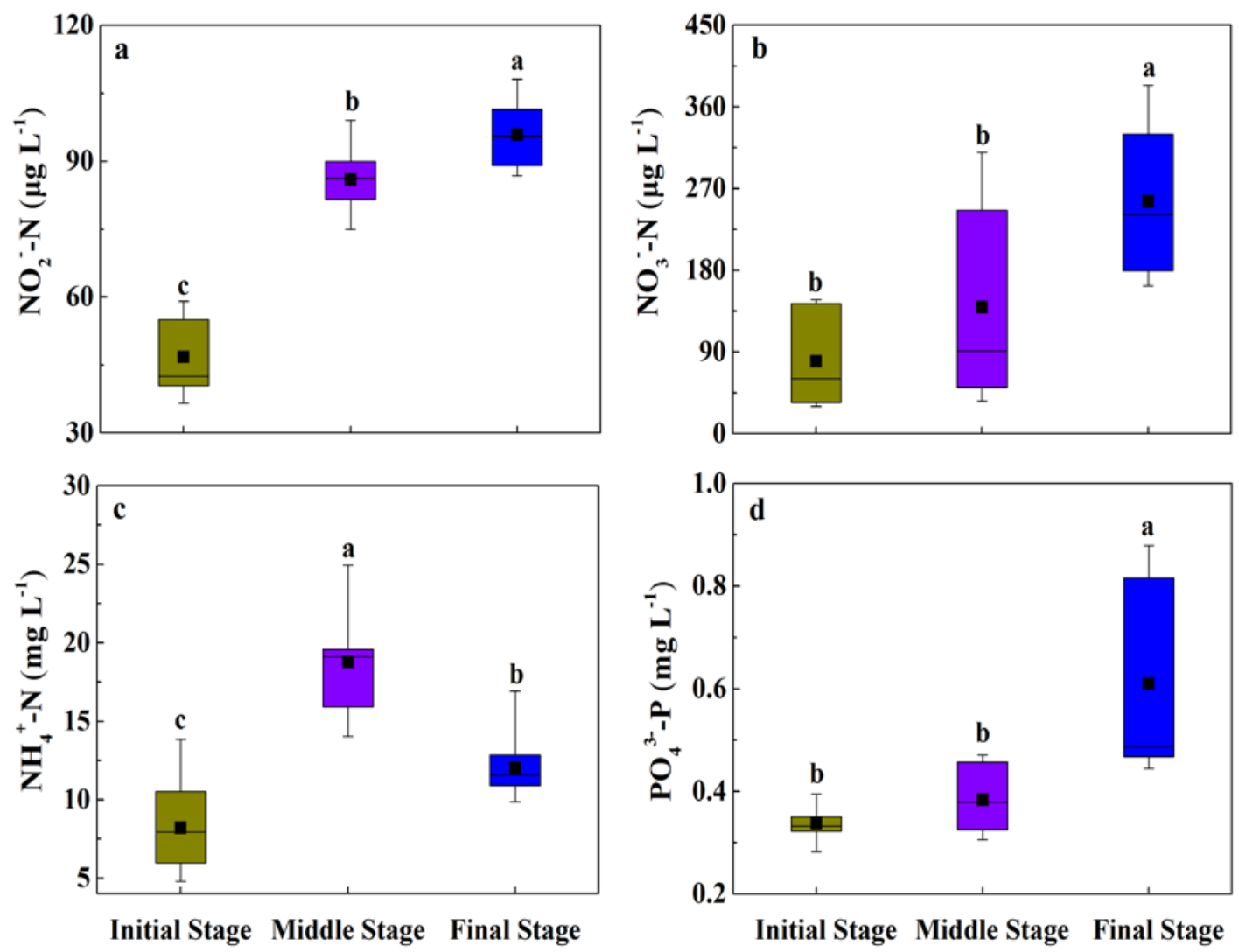

19 Fig. 5. Temporal variations of porewater nutrient concentrations in the shrimp pond

20 sediment at the Min River estuary. The boxes, center line, and whiskers represent the

$2125^{\text {th }}-75^{\text {th }}$ percentiles, median value, and $5^{\text {th }}$ and $95^{\text {th }}$ percentiles, respectively. The

22 square represents the area-weighted average $(n=9)$. Different lowercase letters indicate

23 significant differences $(p<0.05)$ in mean concentrations among growth stages. 

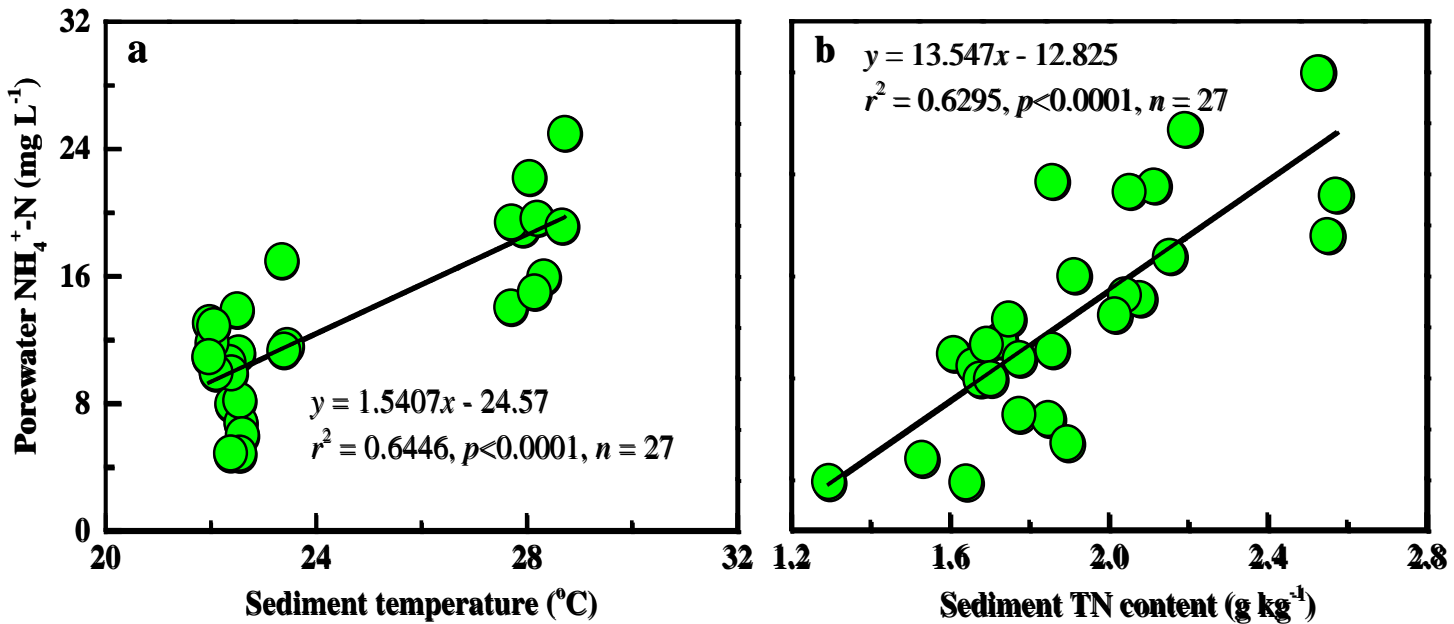

Fig. 6. Relationships between porewater $\mathrm{NH}_{4}{ }^{+}-\mathrm{N}$ concentrations and (a) sediment

26 temperature and (b) TN contents from the shrimp ponds at the Min River estuary. 

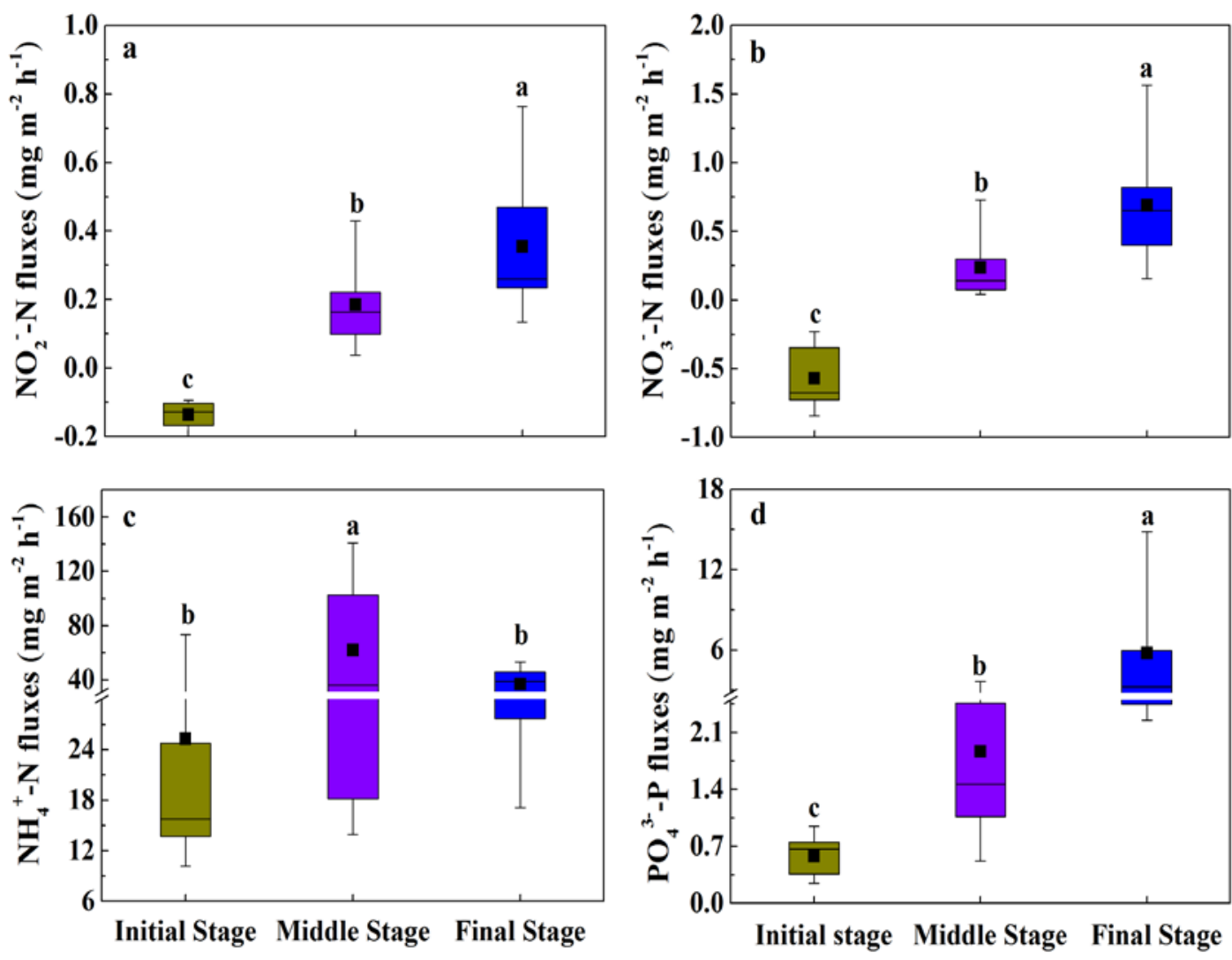

28 Fig. 7. Temporal variations of nutrient fluxes across the sediment-water interfaces in

29 the shrimp ponds at the Min River estuary. The boxes, center line, and whiskers

30 represent the 25 th -75 th percentiles, median value, and 5 th and 95 th percentiles,

31 respectively. The square represents the area-weighted average $(n=9)$. Different

32 lowercase letters indicate significant differences $(p<0.05)$ in mean fluxes among

33 growth stages. 